\title{
Cele houre memes: An Eccentric English Psalter-Hours in the Huntington Library
}

\author{
Alexa Sand
}

\begin{abstract}
ABS TRACT The Ellesmere Psalter-Hours (EL $9 \mathrm{H}_{17}$ ) consists of two distinct but related manuscripts, an earlier Psalter and a later partial Book of Hours written and illuminated in England between about 1310 and 1325. Alexa Sand shows what this unusual book reveals about lay devotion as an expression of class ambition and social networking among the gentry of northwestern England in this period of internecine strife and political turmoil. The manuscript's material structure and its iconographic, textual, and heraldic contents reflect its emulation not only of similar prayer books created for laywomen belonging to the gentry class but also of specific products of a higher level of patronage extending from the upper aristocracy into the ranks of royalty itself. In particular, the book's connection to the Nuremberg Hours indicates the degree to which devotional piety was linked to social aspiration. KEY WORDs: Pabenham-Clifford Hours; Isabel de Harcla; Short Hours of the Cross; Edmund of Abingdon; Mirour de Seinte Eglyse
\end{abstract}

\begin{abstract}
A COMBINED PSALTER AND HOURS of mixed English use now in the collection of the Huntington Library presents valuable evidence about the complicated nexus of patronage, devotion, political affinity, and social performance in the troubled England of the early 130os. This eclectic book, which dates to between 1310 and 1325, combines a rather unusual, unfinished manuscript of the Hours of the Passion and of the Virgin with an earlier manuscript of the Psalter that is both complete and more conformist. Following the practice of the curators at the Huntington, I refer to this manuscript as the Ellesmere Psalter-Hours, a name stemming from its place in the collection of Ellesmere manuscripts acquired by Henry E. Huntington from Sotheby's sale of the Bridgewater library in $1917 .^{1}$
\end{abstract}

1. The manuscript entered the Bridgewater library very early, as attested by the shelfmark inscribed on folio 1 by the hand of John Egerton, first Earl of Bridgewater (1579-1649). See C. W. Dutschke, Guide to Medieval and Renaissance Manuscripts at the Huntington Library, 2 vols. (San Marino, Calif., 1989), 1:32.

Pp. 171-211. (@2012 by Henry E. Huntington Library and Art Gallery. ISSN 0018-7895 | E-ISSN 1544-399x. All rights reserved. For permission to photocopy or reproduce article content, consult the University of California Press Rights and Permissions website, http://www.ucpressjournals.com/reprintInfo.asp. DOI: 10.1525/hlq.2012.75.2.171.

HUNTINGTON LIBRARY QUARTERLY | VOL. 75, NO. 2 
The two volumes, bound together since the Middle Ages, both savor of upperclass lay ownership, infused with Mendicant flavor. Furthermore, the inclusion of abundant heraldry and the references in the calendar and litany to specifically Mercian saints situate the manuscript's original owner or owners in the diocese of Lichfield, the episcopal seat of Staffordshire and the surrounding region. Stylistically and in terms of its conception, however, the book has strong ties to the lively and inventive circle of lay illuminators and scribes associated in this period with East Anglia, particularly with the city of Norwich. ${ }^{2}$ Furthermore, heraldic elements in the decoration of the Psalter point toward Cumberland and the Scottish Marches and help narrow down the probable date of the earlier portion of the manuscript. As for the addition of the Hours, in its combination of Anglo-Norman and Latin texts, and in its interest in Passion iconography, it is a close cousin to the stylistically related De Bois Psalter-Hours (Morgan Library [New York], M.70o) and to the Neville of Hornby Hours (British Library, MS Edgerton 2781), both studied by Kathryn Smith; as well as to the Pabenham-Clifford Hours (Fitzwilliam Museum [Cambridge], MS 242). 3

The manuscript has received only passing attention from scholars; Lucy Freeman Sandler's entry in Gothic Manuscripts and Consuelo Dutschke's entry in Guide to Medieval and Renaissance Manuscripts at the Huntington Library are the only published notices that treat it in its own right. 4 Sandler and Dutschke concur that the book belongs to the second decade of the fourteenth century, with additions after 1323, and that it has stylistic links to East Anglia.5 Sandler identifies the later of the two miniaturists involved as the same hand that illustrated the Apocalypse in a manuscript now in Oxford, the Selden Supra Gesta infantiae salvatoris (Bodleian Library, MS Selden Supra 38, part 2). ${ }^{6}$ The recent rediscovery of another, somewhat later East Anglian manuscript, the Macclesfield Psalter, and the new developments in scholarship on the network of patronage and production of devotional manuscripts in the fraught political context of Edward II's reign that this discovery has spurred, call for a more searching

2. For a thorough and revelatory discussion of fourteenth-century Norwich as a center for manuscript production, see Caroline S. Hull, "The Douai Psalter and Related Manuscripts” (PhD diss., Yale University, 1994).

3. Kathryn Smith, "The Neville of Hornby Hours and the Design of Literate Devotion," Art Bulletin 81, no. 1 (1999): 72-92; Smith, Art, Identity, and Devotion in Fourteenth-Century England: Three Women and Their Books of Hours (Toronto, 2003); and The Cambridge Illuminations: Ten Centuries of Book Production in the Medieval West, ed. Paul Binski and Stella Panayatova (London and Turnhout, 2005), 191-93.

4. Additional bibliography is limited to Eric Millar, English Illuminated Manuscripts, vol. 2 (Paris and Brussels, 1928), 85n251 (a generous footnote); S. de Ricci, Census of Medieval and Renaissance Manuscripts in the United States and Canada, 2 vols. (New York, 1935), 1:130-31; Aspects of Medieval England: Manuscripts for Research in the Huntington Library, an exhibition prepared for the Medieval Academy of America, April 14, 1972, no. 35 (brief description); and Lucy Freeman Sandler, "An Early Fourteenth-Century English Psalter in the Escorial," Journal of the Warburg and Courtauld Institutes 42 (1979): $72 \mathrm{n} 32$ (a footnote with a brief description of the manuscript).

5. Sandler, Gothic Manuscripts, 1285-1385, 2 vols. (London, 1986), cat. no. 53 (2:61-62); Dutschke, Guide, 1:31-33.

6. Sandler, Gothic Manuscripts, 2:62. 
analysis of the Ellesmere Psalter-Hours. Though not as lavish as some of its more flamboyant contemporaries, it adds depth to the emerging picture of the complex relations between devotion, language, and the visual arts in early fourteenth-century England.

This study of the Ellesmere Psalter-Hours seeks two ends: to provide a more indepth description of the manuscript than has previously been given in print, and to investigate the place of this unusual book in the wider landscape of English illumination in the first quarter of the fourteenth century. In particular, I explore the textual and pictorial connections between the Ellesmere Psalter-Hours and the Nuremberg Hours (Stadtbibliothek [Nuremberg], hs. Solger $4.4^{\circ}$ ). Iconographic and conceptual similarities between the two works - which are otherwise very different in terms of their degrees of artistic polish, their probable origins, and their subsequent historiespoint to the need for a reconsideration of the relationship between French and English book illumination in this critical period.

\section{Description}

\section{Contents: The Two Manuscripts}

The Ellesmere Psalter-Hours began as two separate though closely related manuscripts, a Book of Hours and a Psalter. The date at which they were joined cannot be determined, but this likely occurred before the end of the sixteenth century, when the manuscript entered the Bridgewater library, since a shelfmark in the hand of the first Earl of Bridgewater, John Egerton, appears on folio 1 of the present binding.7 The combined book is an example of a type of manuscript that was most common in the period between about 1270 and 1330-the combined Psalter-Hours. These books, unlike independent Psalters or Books of Hours, never attained wide popularity, perhaps due to their inherent bulkiness. Those that do survive generally represent higher-end book production in their period, and this in itself suggests that such manuscripts were not only useful in devotional practice but also reflections of status.

The present manuscript fits the typical profile of such books, rich as it is in illumination. It seems probable to me that even if the two sections of the book were not bound together shortly after the middle of the fourteenth century, when they were given to Hampole Priory in Yorkshire (as a note in the calendar indicates), they were used in association with one another from an early date and were intended, after the creation of the second volume, to function as a pair. Because certain elements of the Hours portion point toward a later date (post-1323), while aspects of the Psalter situate it before 1314, I propose that the Hours was commissioned as a supplement to the existing Psalter, following the shifting trends in personal devotion toward the use of Books of Hours and toward more emotive attention to the Passion, which were characteristic of the early fourteenth century.

The Psalter, while earlier, occupies the second half of the manuscript, beginning on folio 36 with a calendar illustrated with astrological signs in roundels (except for 
January, where the labor of the month is illustrated instead), followed by the ferial Psalter with its eight daily divisions marked by large historiated initials; the last initial, for Psalm 109, has been removed, along with its entire page. However, the remaining seven initials follow a pattern well established in thirteenth- and early fourteenthcentury English Psalter illumination, particularly in the inclusion of Jonah at Psalm 68 (Salvum me fac) rather than David immersed in the waves, as was more common in Continental Psalters. ${ }^{8}$ The folios with major divisions of the text also feature heraldic escutcheons and elaborate, foliated text-frames abundant in carefully drawn and tinted marginalia. Secondary initials receive much more artistic attention than in most of the first part of the book and include a variety of inhabitants, ranging from hybrid monsters to attentive faces. The prolific pen-scrolls that ornament the colored initials are extremely delicate and complex, similar in form to the pen work in the first portion of the book but drawn with more refinement. The ferial Canticles begin on folio $175 \mathrm{~V}$ with a large historiated initial for Confitebor tibi (Isaiah 12:1-6). A coiffed laywoman kneels before an altar with a statuette of the seated Virgin and Child, holding an open book with the words "Ave Maria gratia plena" in her hands (fig. 1); this could very well be a portrait of the original destinaire of the manuscript. A litany and memorial begins on folio 188 and continues to $192 \mathrm{~V}$, ornamented with finely executed blue and gold initials, as well as several inhabited initials. The office to the dead begins on folio $193 \mathrm{v}$ with a large initial P (Placebo) depicting a white-robed monk standing and holding an open book in his hands. This text, highly abbreviated toward its end, concludes on folio 199, just a few lines shy of the bottom of the page.

The portion of the manuscript bound at the front of the current volume (though later in execution) constitutes a partial Book of Hours. It includes standard texts, such as the Hours of the Passion (folios 2-12), the Hours of the Virgin (folios 19-25v), and the Psalter of Saint Jerome (folios 26-35), as well as some more unusual entries, including a series of Anglo-Norman rhymed couplets dedicated to the Crucifixion (attributed in the rubric to "Pope Urban"), embedded in the Latin text of the short Hours of the Cross. 9 The memorials in the Hours of the Virgin indicate Dominican influence; they are dedicated to Saint Dominic (folio 24v), Saint Peter Martyr (folio 25), the Order

8. The Ellesmere cycle is as follows: folio 42 (Psalm 1), David seated, playing the harp; folio 61 (Psalm 26), David, seated, with raised hand, book in lap; folio $73 \mathrm{v}$ (Psalm 38), David seated, pointing to his tongue; folio 85v (Psalm 52), David seated, pointing to a capering fool; folio 97v (Psalm 68), bust of Christ, blessing, above, with Jonah emerging from the whale's mouth below; folio 113v (Psalm 8o), David, seated, playing bells; folio 129v (Psalm 95), three clerics singing from a choirbook, while a third, outside the initial, has lower extremities of an animal. The missing initial may have yielded additional clues about the manuscript's origins (since all the initial pages also have heraldic escutcheons), but the usual subject for Psalm 109, the Mercy Seat Trinity, was probably included in the initial. Unlike many English Psalters of this period, the Ellesmere example does not retain the additional divisions at Psalm 51 (often illustrated with scenes of murder or self-murder) and at Psalm 101 (where a portrait of the book's owner, or of David or Ecclesia in prayer, was often placed). For discussion and comparative tables of illustration cycles in English Psalters, see Günter Haseloff, Die Psalterillustration im 13 Jahrhundert, Studien zur Buchmalerei in England, Frankreich, und den Niederlanden (Kiel, Germany, 1938), 6o-64, 118-19.

9. See the section on texts, below, for further discussion of both the Latin and Old French texts dedicated to the Crucifixion. 
of Preachers (folio 25), and Saint Thomas Aquinas (folio 25v). These saints are not to be found in the calendar attached to the Psalter. This suggests either that the book changed hands or that its owner underwent a shift in religious orientation sometime between the early 1310 s and the creation of the Hours portion, perhaps under the influence of a Dominican spiritual adviser.

The program of illumination in the Hours indicates its unfinished status. It opens with a pictorial frontispiece sketched in but not colored (fig. 2), and folios 2, 19, and 26 feature blank spaces where a large, presumably historiated initial would have been placed. Throughout the section, one finds decorative line-fillings laid down in a thick, bisque-colored paint, a preparatory base for the blue-and-gold line-fillings that feature on the more finished pages of the book. Secondary initials were completed, rather sloppily, in red, blue, gold, white, and green, as were foliated embellishments around the text block, especially in the Hours of the Passion. The contrast between the smudged and blotted coloring of these elements and the tidiness of the comparable elements elsewhere in the manuscript suggests that the work was done either by an untrained apprentice at the last moment or by an amateur attempting at a later time to improve the unfinished look of the book.

The only part of the first portion of the manuscript that has a professionally finished look is the section with the Latin Short Hours of the Cross and an accompanying Anglo-Norman paraphrase. Here, initials are completed with very finely drawn white accents on the colored grounds, pen-scrolls are daintily executed, and the leaves and buds-which look so gauche in the preceding and subsequent texts, the Hours of the Passion and the Virgin, respectively-provide examples of subtle coloring and careful highlighting. Furthermore, a series of paired, framed miniatures in the bottom third of folios $14 \mathrm{~V}-17 \mathrm{~V}$ exhibit a similar attention to finish (see figs. 10-13). These illustrate the Anglo-Norman couplets dedicated to the Crucifixion, and show signs of wear that suggest a devout reader much in the habit of kissing or touching them. I return below to the significance of these images for understanding the character of the manuscript as a whole.

Even this brief survey of the contents begins to suggest the separate identities of the two portions of the manuscript; differences in quality and degree of finish certainly indicate that of the two, only the Psalter was a complete manuscript when it left the workshop. Nonetheless, the two parts complement one another nicely in terms of their contents-the Hours portion, for example, does not include a calendar or the office of the dead, which indicates that it was never intended to function as an independent book but rather as a pendant to a Psalter already containing these elements. Though the inscription at the foot of the calendar page for January, recording the donation of the book to the Cistercian priory of Hampole, suggests that at the time of the gift, around 1350, this was the first page of the book (the usual place for such notations), I would venture that the two parts were given together and combined while held at the nunnery. After the Dissolution, it would then have passed as one volume into the hands of John Egerton. ${ }^{10}$

10. For more discussion of the donation note, see the discussion of provenance, below. 




FIGURE 1. Lady at prayer, possibly an owner portrait, initial to the ferial Canticles; Ellesmere PsalterHours, fol. 175v (Huntington Library, EL 9 H 17). 

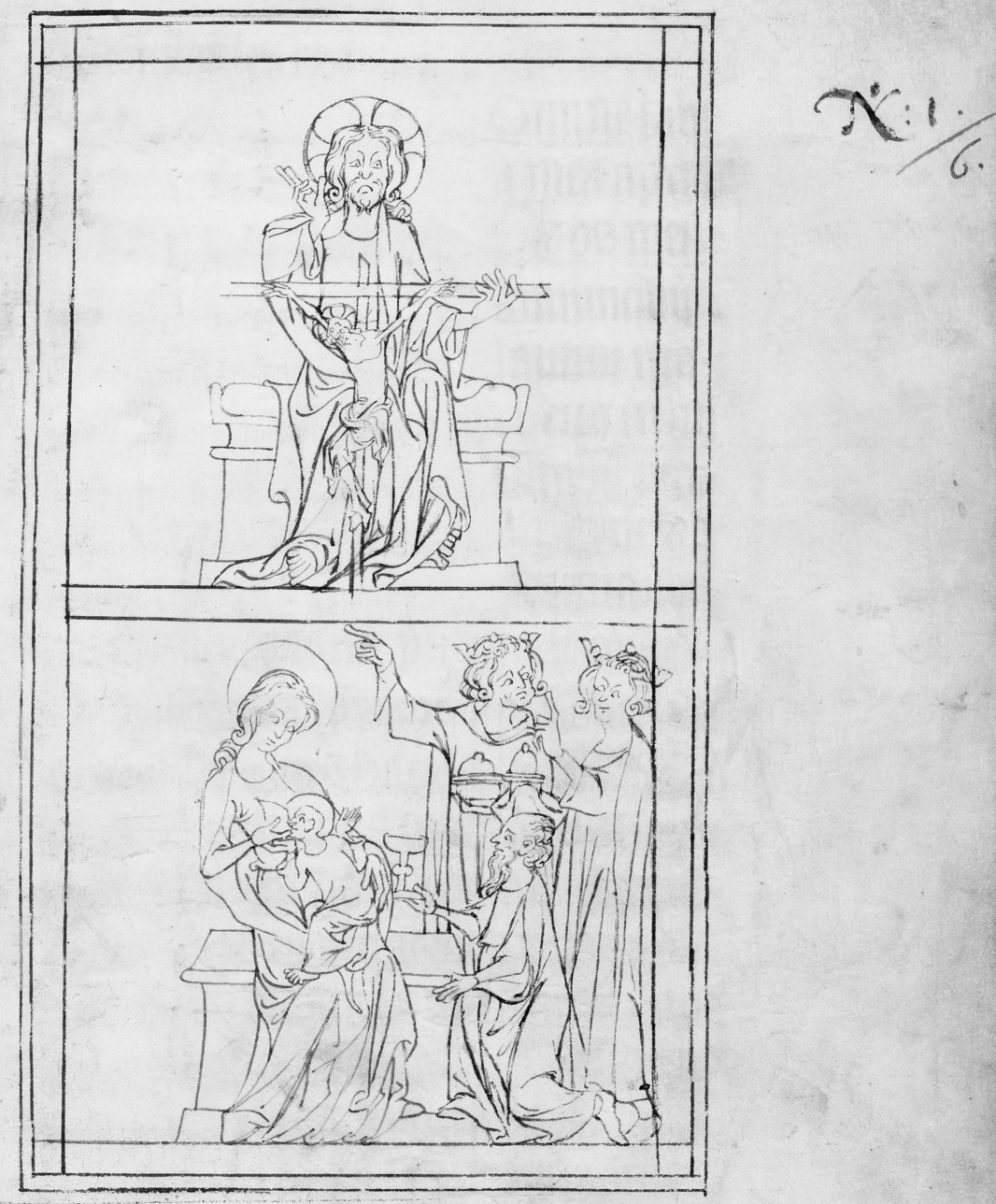

FIGURE 2. Christ in Majesty, Adoration of the Magi; frontispiece, Ellesmere Psalter-Hours, fol. 1. 


\section{Structure}

The physical structure of the Ellesmere Psalter-Hours strongly supports the conclusion that the current volume brings together two distinct but related manuscripts. Although the rather tight, 1840s-style binding makes it difficult to study, the collation is fairly clear. Particularly in the second part of the book, the use of catchwords and scribal notations in the bottom right corner of the first four folios of each quire (that is, on the lower right front of the unbound bifolio) make the quire structure very evident. While such marks are less numerous in the first part of the manuscript, they do occur occasionally; there is a difference, however. In the second part of the manuscript a letter indicates the quire ( $a, b, c$, and so on) and a lowercase Roman numeral (i., ii., iii., iiii.) indicates the bifolio. In the first part of the manuscript, where such notations do occur (as on folios 14-16), the scribe may use only the Roman numeral, or (as on folios 22-25) lower case letters ( $, b, c, d$ ). From these variant practices of notation alone, one has the sense that those responsible for the basic planning of the first part of the book were a little less experienced and professional than those who had made the Psalter.

Closer scrutiny of the folio organization furthers the impression that the Hours portion of the book was put together more haphazardly than the Psalter. The Hours portion is made up of a singleton folio (the frontispiece) and five quires (of 8, 4, 8, 8, and 6 folios, respectively). There is something ad hoc about this portion of the manuscript, an impression confirmed by the unfinished look of the decorative program and the presence of blank and partially blank folios. Quires I (folios 2-9) and II (folios 10-13) comprise the Hours of the Passion. This correlation of text and quire is not usual-in most manuscripts, careful planning allowed scribes to move from one text to the next within a quire, thus avoiding the waste of parchment that we see here with the blank space that stretches from the eighth ruled line of folio 12 to the verso of folio 13 .

At the beginning of the new quire (III, folios 14-21), we have the opening of the short Hours of the Cross. This text continues up to folio 18, which is again blank in its lower third and on its verso. Still in the third quire, the Hours of the Virgin begins on folio 19 (missing the opening initial $\mathrm{D}$, for which space has been left) and continues to folio $24 \mathrm{~V}$, thus crossing from quire III to quire IV (folios 22-29), a shift that is signaled by a catchword ("valemus," at the foot of folio 21v). The subsequent Dominican memoriae and the Psalter of Saint Jerome run into the final quire and end midway down the recto of folio 35. This last text is highly abbreviated at its end and ultimately incomplete. On the whole, it is a shoddy piece of scribal work.

By contrast, the Psalter is regular in its collation, consisting of twenty quires. Of these, almost all are octavos, except the first (VI), which has six leaves, presumably to suit it to the calendar, and quires X and XX, both of which are missing a folio from the text. Most quires conclude with a catchword. The ruling in this portion of the manuscript is also very consistent, and it differs from the first portion in that guidelines constraining the decoration of the margins are lightly inked in on every page, regardless of whether there is marginal ornamentation. In the first part of the manuscript only the 
text block itself is ruled. The parchment, too, differs in the two portions, being thicker and more irregular in the first part, where, for instance, several pages appear to have been cut from the edge of a skin, so that the lower selvage is curved and does not quite extend to the usual dimensions (folios 15, 16).

The physical evidence, ranging from the unfinished character of many pages in the Hours section to the collation of the folios, furthers the case that while complementary, these two sections of the manuscript were not originally conceived of or produced as one volume. The organization of the texts (with the calendar coming after the Hours section) is quite anomalous; most combined Psalter-Hours open with a calendar (if not with a pictorial preface), proceed with the Psalter, and then feature a selection of offices, prayers, and auxiliary texts. On the other hand, because there is no overlap between the two manuscripts in terms of content, and because they share such features as the size of the folio and the text block, the general character of the scribal hand, and the decorative vocabulary, they almost certainly came out of closely related "shops"-or, perhaps more accurately put, practices-within the same twenty-year period.

\section{Style}

The stylistic relationship of the Ellesmere Psalter-Hours to other illuminated books originating from East Anglia in the 1310 s and 1320 s has been well established by Sandler and Dutschke. The paintings in the short Hours of the Cross, with their elegant and somewhat angular figures and restricted but sumptuous palette, confirm close ties between this manuscript and such East Anglian products as the Tickhill Psalter (New York Public Library, Spencer MS 26), the Bardolf-Vaux Psalter (Lambeth Palace [London], MS 233), and the Pabenham-Clifford Hours, all dating to the first two decades of the fourteenth century. ${ }^{11}$ Sandler has also pointed out similarities in a Psalter with strong Austin Friar influence, now in the Escorial, that also contains an illustrated short Hours of the Cross and some Anglo-Norman verses, these dedicated to the name of the Virgin; Sandler connected the Escorial Psalter to the same workshop that produced the Stowe Breviary, firmly dated between 1322 and $1325 .{ }^{12}$ This accords with the post1323 date of the Ellesmere manuscript's Hours portion, perhaps even suggesting that the Stowe/Escorial painter was closely connected or even identical to the Ellesmere painter. On close examination, however, the latter possibility must be ruled out; the painter of the Ellesmere Passion miniatures handles outlines more loosely and prefers a less vivid palette, and such small details as the treatment of white highlights on vine-tendrils in the frame vary between the Ellesmere and the Stowe/Escorial painter as well. Nevertheless, figure style, gesture, and composition have much in common.

The connection between the Psalter illuminations in the Ellesmere PsalterHours and some of the same manuscripts that seem to have close kinship with the later Hours portion can be seen in some of its historiated initials and decorative elements. On folio 97v, the magnificent initial S of the Salvum me fac (Psalm 68) depicts Jonah,

11. Sandler, Gothic Manuscripts, 2:62; Dutschke, Guide, 1:31. 12. Sandler, "An Early Fourteenth-Century Psalter," 76. 


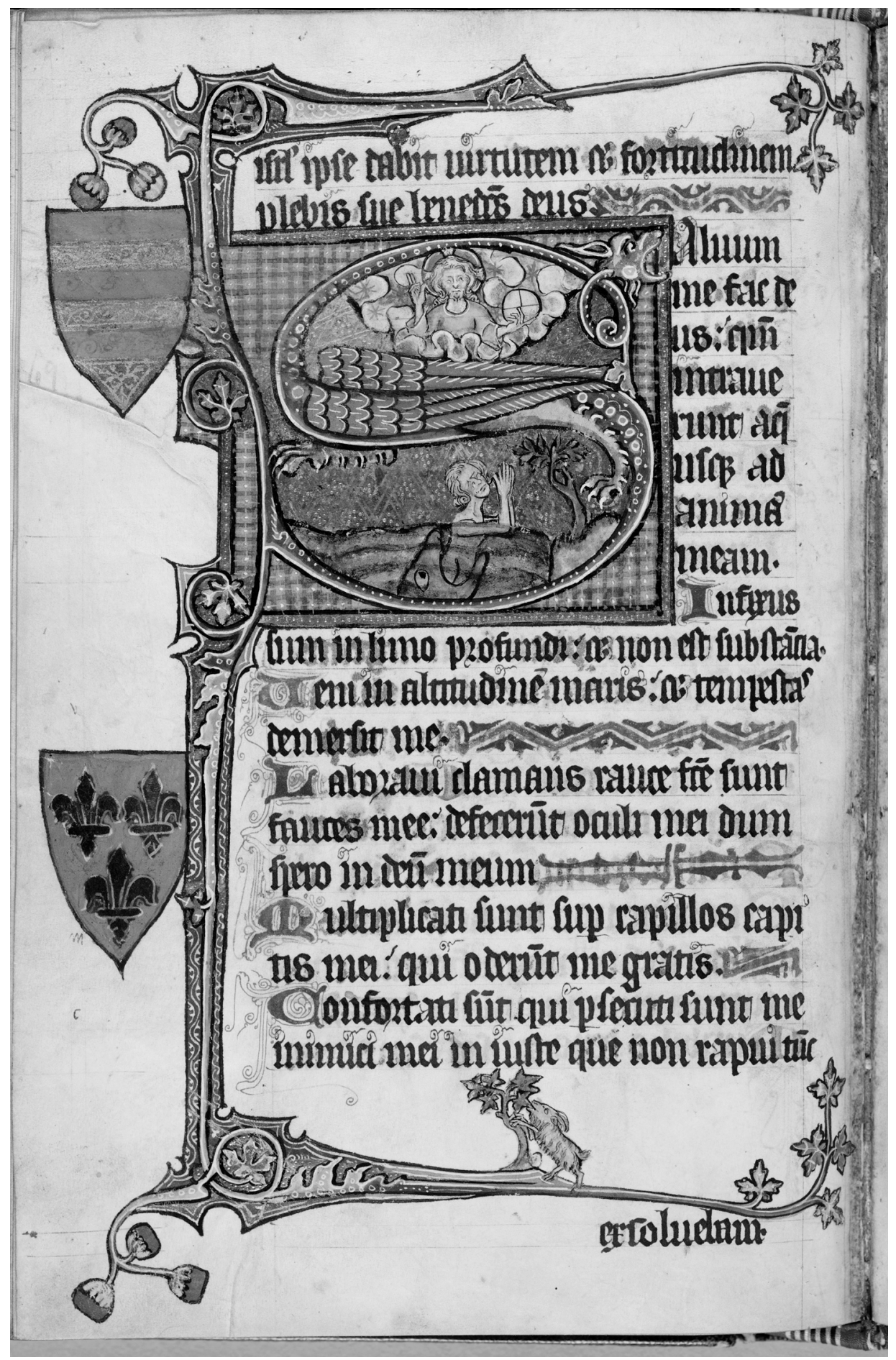

Figure 3. Jonah, initial to Psalm 68; Ellesmere Psalter-Hours, fol. 97v. 


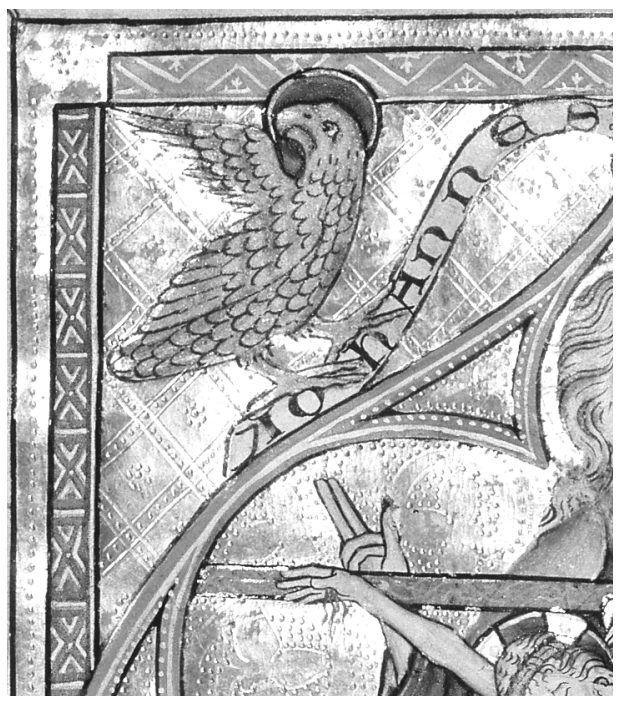

FIGURE 4. Detail of ground, Mercy Seat Trinity; Pabenham-Clifford Hours. (CFitzwilliam Museum, Cambridge; MS 242, fol. 28v.

naked and partially submerged under transparent green water, a sea-monster swallowing his nether half; above, Christ appears in a burst of rippling blue-and-white clouds spangled with red starbursts (fig. 3). The ground for this elegantly painted scene is gold, embossed with a pattern of bordered lozenges containing six-petal rosettes. A virtually identical ground appears in the Mercy Seat Trinity full-page miniature in the Pabenham-Clifford Hours of circa 1315 (folio 28v), and other similarities between the manuscripts emerge on closer examination (fig. 4). For example, the green-andorange trilobe florettes favored by the artist of the Pabenham-Clifford Hours, each with its centered white spot, also appear frequently in the Psalter of the Ellesmere manuscript. The motif of a gray long-haired ram with its forelegs up on the trunk of a tree also occurs in both manuscripts (folio 29 in Fitzwilliam 242, folio 97v in E9 $\mathrm{H} 17$ ), suggesting recourse to a similar pattern book or repertoire of marginalia (fig. 5 , fig. 6). ${ }^{13}$ The family for whom the Pabenham-Clifford Hours was made belonged to the gentry class, like the probable owners of the Ellesmere Psalter-Hours, rather than the high aristocracy; it has been suggested that this could be a factor in the somewhat ostentatious character of the book and its enthusiasm for heraldry, another shared trait

13. The motif (which Lillian Randall calls “a goat on hindlegs," but which I believe would more accurately be described as "a ram stuck in the briers," as in Gen. 22.13) is relatively unusual in English illumination. Randall cites thirteen instances, of which eleven originate in Flanders or northern France; only two (the Pabenham-Clifford Hours and the Smithfield Decretals [British Library, MS Royal 1o.E.IV]) are English. The illumination of the Smithfield Decretals postdates the Ellesmere manuscript's Psalter, and it's therefore reasonable to assume that the motif was imported from Flanders, a connection I pursue at greater length in the discussion of the Passion miniatures below. See Randall, Images in the Margins of Medieval Manuscripts (Berkeley, Calif., 1966), 104. 


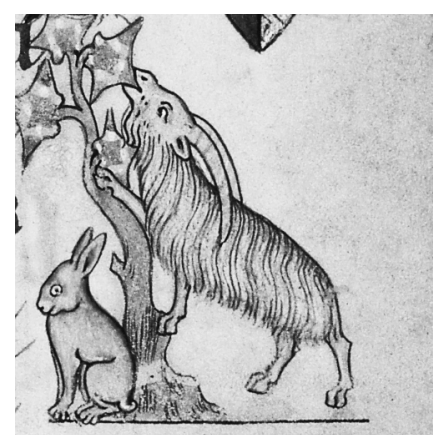

FIGURE 5. Ram, marginal illumination; Pabenham-Clifford Hours, fol. 29. (CFitzwilliam Museum, Cambridge.

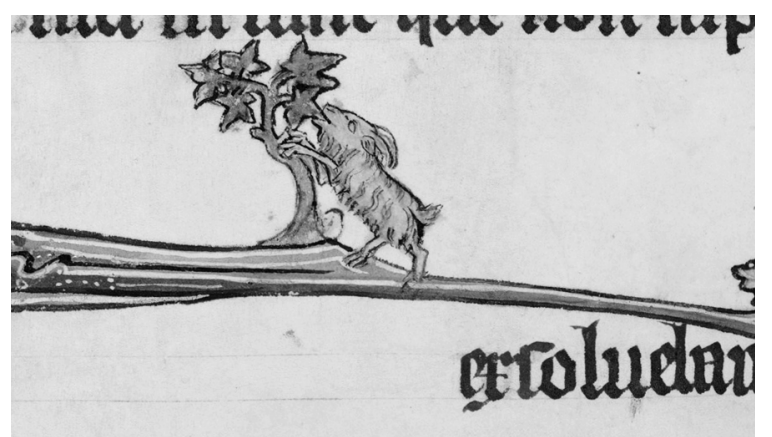

FIGURE 6. Ram, marginal illumination; Ellesmere PsalterHours, fol. 97v.

with the Ellesmere Psalter-Hours. ${ }^{14}$ Thus, both the earlier and the later portions of the book have traits in common with the Pabenham-Clifford Hours.

Of even greater interest is the relationship between the painter of the Hours and the painter of the Psalter. For despite the marked difference in quality of scribal production in the two portions of the manuscript, the finished paintings in the initials of the Psalter have much in common with the painted diptychs in the Short Hours of the Cross and the unfinished prefatory miniature of the Mercy Seat Trinity and the Adoration of the Magi. In terms of the handling of color and shading, the palette is virtually identical, and the modeling of figures and draperies very similar-for example, the use of diluted white pigment to highlight the edge of a fold in a pink garment, seen in both the portrait of a lady at prayer at folio 175V (fig. 1) and the Arrest at folio $14 \mathrm{~V}$ (fig. 10). Furthermore, the frontally depicted Vultus Dei in the two-line initial D on folio 179 (fig. 7) strongly resembles the frontally depicted face of God the Father in the Mercy Seat Trinity of folio 1 (fig. 2). Both look a bit cross-eyed and scowl forebodingly. Other details, such as the rendering of eyes, mouths, eyebrows, crowns, and hair, are also very similar. The later artist, then, was either scrupulous in the imitation of the earlier hand that illuminated the Psalter initials, or the same person, which is intriguing in light of the generally lower quality of the Hours portion.

\section{Date and Provenance}

The inclusion of a memorial to Saint Thomas Aquinas on folio $25 \mathrm{~V}$ virtually confirms that the Hours section of the manuscript was put together after 1323, when the great Dominican theologian was canonized. As for the earlier Psalter, the date is not as immediately evident, but the localization of the originally intended owner of the book to the diocese of Lichfield is clear from the calendar and litany. Both contain numerous

14. Fitzwilliam Museum, "The Cambridge Illuminations: Private Devotion: Humility and Splendor" (http://www.fitzmuseum.cam.ac.uk/gallery/cambridgeilluminations/themes/4.html, accessed May 27, 2010). 


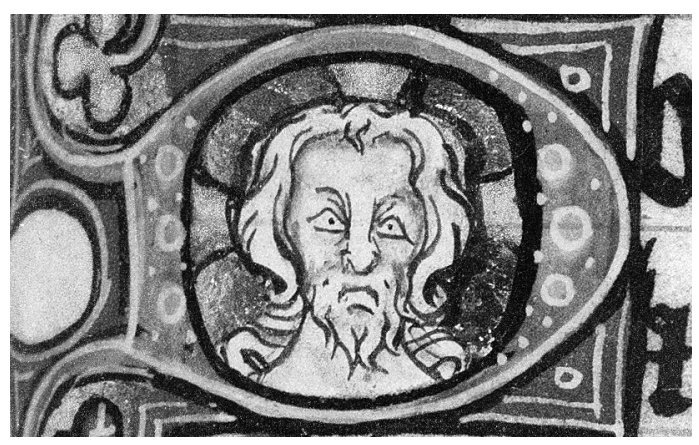

FIGURE 7. Vultus Dei, initial from the Psalter;

Ellesmere Psalter-Hours, fol. 179.

references to English saints, including such standards of the Sarum Use as Edward the Confessor, Thomas à Beckett, Botulph, and Alban, but also including some more unusual figures. Saint Chad of Lichfield, the Anglo-Saxon bishop-missionary of Mercia, Saint Kenelm (a Mercian king and martyr), Saint Edith of Polesworth (a Mercian princess and abbess, also possibly mentioned in the litany), 15 Saint Modwena (a semilegendary Mercian abbess, mentioned only in the litany), and Saint Mildred (a Mercian princess, mentioned only in the litany) point to an association with the region of the ancient kingdom of Mercia, roughly equivalent to the West Midlands. Chad receives special attention; his feast day (March 1) is marked in gold, an honor he shares with only Thomas à Beckett, several apostles, and the feasts of Christ and Mary. Churches dedicated to all of the Mercian saints mentioned in the calendar and litany were under the supervision of the Bishop of Lichfield, whose cathedral was dedicated to Saint Chad and Saint Mary. Chad's relics were enshrined at Lichfield Cathedral in a magnificent twelfth-century reliquary, freshly installed in the newly built Lady Chapel by Bishop Walter Langton in $1296 .^{16}$

The abundant heraldic decoration found on the illuminated pages that mark each of the ferial divisions of the Psalter also points to an affiliation with aristocratic families with strong ties to the area around Lichfield as well as farther north, into Cumbria. In addition, the heraldic decoration provides unexpected clues to the terminus ante quem for the manuscript. There are fourteen heraldic charges represented (one is repeated, for a total of fifteen blazons), mostly appearing in pairs in the frames of the folios that include large historiated initials to the ferial divisions of the Psalter. Of these,

15. The identification with Saint Edith of Polesworth, rather than the more popular Edith of Wilton, is based on the date of the feast, July 15. Polesworth (where she was one of the royal, AngloSaxon abbesses) is not far from Birmingham, in Warwickshire, well within the ancient boundaries of Mercia. She is named only as Edith in the litany.

16. James Charles Wall, Shrines of British Saints (1905), 98. 
several can be identified as belonging to families that either held land within the diocese of Lichfield or had political and/or matrimonial ties to those that did. These include the Vernons of Harlaston (folio 61), the Dacres (folio 73), the Harclas (folio 85v), the Cliffords of Skipton (folio 129v, a different branch of the family from that associated with the Pabenham-Clifford Hours, but related), and the Marmions (folio 175v). ${ }^{17}$ The Vernons, whose arms appear twice on folio 61 (once in ordinary, once differenced by a martlet, as if to indicate both senior and junior branches of the family), are at the nexus of this group; they had alliances by marriage or by politics with all of the others. The bearings most closely associated with the Vernon family, argent fretty sable with a canton gules, one with, and one without, a martlet argent in the canton, are given pride of place in the decorative program, at Psalm 26 (fig. 8), following only the arms of England and Edward the Confessor represented on folio 42 at the opening of the Psalter. ${ }^{18}$ For this reason, Sandler named the volume "the Vernon Psalter."19

Some investigation of the Vernons and their coterie sheds a good deal of light on the probable origins of the Psalter and also gives us a glimpse of the rowdy frontier mentality of northwestern England during the reigns of Edward I and Edward II. The blazons in the manuscript correspond to a group of families whose affairs were intimately entangled with one another, not always in a friendly way, and whose involvement in the larger political affairs of the time-ranging from the Scots border wars to the judicial murder of Piers Gaveston, the royal favorite-was complicated, aggressive, and above all self-promoting. The ferocious ambition of the landed knightly class in early fourteenth-century England has been well documented, and the Vernons, it seems, were no exception to the general rule of the land-owning miles jockeying to position themselves as what David Crouch has named "the superior knighthood," an elite class of chivalric families who used heraldry, among other things, as a distinguishing social marker. ${ }^{20}$ By the end of the fourteenth century, almost all the families represented in the Ellesmere Psalter's heraldic ornament would either have attained parliamentary peerage or extinguished themselves trying.

17. For a description of all the coats of arms, see The New Palaeographical Society, ser. 2, pt. 3 (1915), text and plate 69, with reproductions of fols. 15 and 61. I would question the identification of the blazon on the lower left margin of folio 97v (Vert a cross paty argent) with the Boydell family, whose bearing was vert a cross paty or, according to most sources and as recorded for the mid-fourteenth-century glass at Grappenhall Church in the Boydell-endowed chantry chapel there. On the Grappenhall glass, see Thomas Barns, "The Architectural Antiquities of the Parish Church of Saint Wilfrid, Grappenhall, County Chester," Transactions of the Historic Society of Lancashire and Cheshire 33 (1880-81): 100-101; Penny Hegbin-Barnes, The Medieval Stained Glass of Cheshire, Corpus Vitrearum Medii Aevi, Great Britain, summary volume 9 (London, 2010), 114n385. I have identified some further blazons, most notably those of the Marmions of Tamworth Castle and of Adam de Gordon, a Scots marcher lord, as discussed below.

18. For the identification of this variant on the Vernon ordinary charge of argent fretty sable

(Burke's Peerage), see The New Paleographical Society ser. 2, pt. 3, text and plate 68.

19. Sandler, "An Early Fourteenth-Century English Psalter," 72.

20. David Crouch, The Image of the Aristocracy in England, 1100-130o (London and New York, 1992), 153 . 


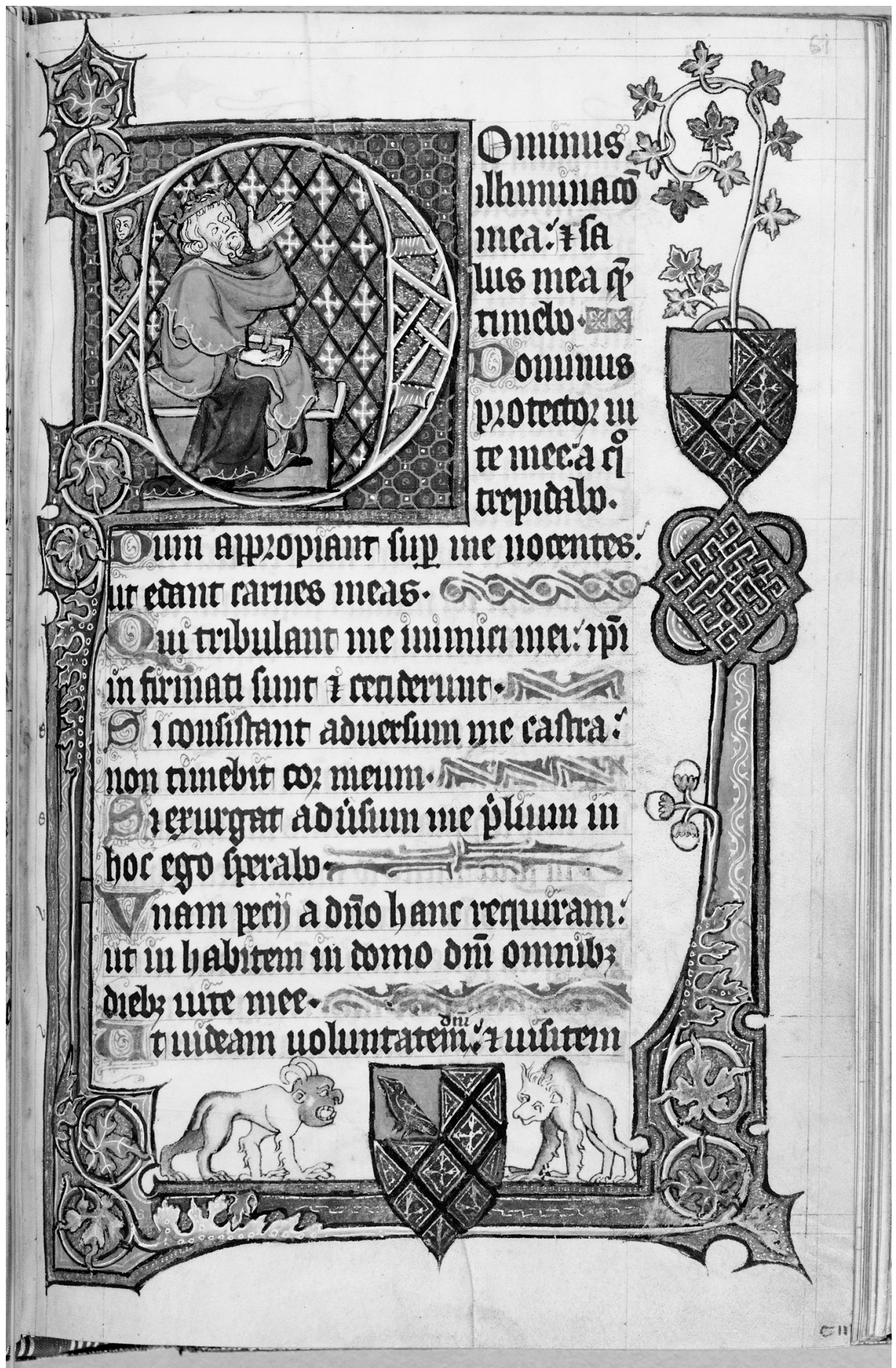

FIGURE 8. David, seated, with raised hand, book in lap, initial for Psalm 26, with de Vernon arms in border; Ellesmere Psalter-Hours, fol. 61. 
At the center of things are the Vernons of Harlaston in Staffordshire and the Harclas of Hartley in Westmoreland. Around 1278, Sir Michael de Harcla married his foster son, Richard le Franceys, to his daughter Isabel; Richard would have been about fifteen at the time, and because he was a minor and heir to considerable lands in Cumbria, Westmoreland, Derby, Cheshire, Staffordshire, and Buckinghamshire, some held in chief from the king, the marriage aroused interest from the royal inquisitors into his father's estate. ${ }^{21}$ To Michael de Harcla, the young man must have seemed a golden opportunity: he would inherit the wealth not only of his father, Gilbert le Franceys, but also of his mother, Hawisa de Vernon, herself heiress of the junior branch of a Domesday family descended from the first Norman Baron of Shipbrook in Cheshire. In fact, almost as soon as he came into his majority he began to appear in the legal records of Staffordshire under the name Richard de Vernon. ${ }^{22}$ Of these three families (le Franceys, de Vernon, and de Harcla), the de Vernons and the de Harclas are clearly indicated by the heraldry in the manuscript. The de Vernon charge appears, as noted, twice at Psalm 26, ${ }^{23}$ and the de Harcla charge, argent, a cross throughout gules with a martlet sable in the first quarter, blazons a rectangular banner on folio $85 \mathrm{v}$ in the upper left margin, next to the penultimate verse of Psalm 51, "But I, as a fruitful olive tree in the house of God, have hoped in the mercy of God for ever" (fig. 9). The banner form is not employed elsewhere in the manuscript, calling attention to this blazon that appears more closely connected to the text (it is "hung" on the ascending frame element), just where the personal pronoun "Ego" begins a line of text particularly concerned with fertility. This is very suggestive though hardly solid evidence that Isabel de Harcla may have been the originally intended viewer and user of the Psalter portion of the manuscript. Just below her father's blazon, next to the historiated capital for Psalm 52, an escutcheon with the charge vert, a cross patoncé argent may allude to Richard de Vernon's other lineal name, le Franceys. A tomb slab in Urswick Church in Cumbria that bears a similar motif was dedicated to an Amicia le Franceys (died ca. 1300), possibly Gilbert's sister, but the state of the slab and the state of knowledge about the le Franceys genealogy in the region make certain identification impossible. ${ }^{24}$

21. Frederick Ragg, "Maud's Meaburn and Newby: De Veteripont, Le Franceys and De Vernon," Transactions of the Cumberland and Westmorland Antiquarian and Archeological Society, n.s., 12 (1912): 312-94 at 324

22. Ibid., 331.

23. The differencing (marking the lineage's main blazon with symbols indicating the subordinate status of the bearer) that leaves the canton gules empty in the upper escutcheon and includes the martlet in the lower perhaps refers to the rise of Richard's status with his marriage to Isabel, whose Harcla arms (for example, the martlet sable in the first quarter) seem here to join with his differenced version of the Vernon arms (Richard's mother's family being the junior branch). Alternatively, the martlet sometimes refers to the landlessness of younger sons (without legs, the martlet cannot land), and with his inheritance of the Harlaston and Haddon manors through his mother, Richard put his feet firmly on the Staffordshire soil as a member of the landed gentry. Unfortunately, the missing martlet in the upper escutcheon could just as easily be an oversight by the illuminator.

24. The slab is first mentioned in print by H. Gaythorpe in the Barrow Naturalists' Field Club and Literary and Scientific Association's Annual Report and Proceedings 3, no. 2 (1882): 108. It is the subject of a query by Rev. T. H. Postlethwaite, Notes and Queries, 1oth ser., 6 (1906): 88. My thanks to Rev. Colin Honour, vicar of Urswick Church in Ulverston, South Cumbria, who kindly responded to 


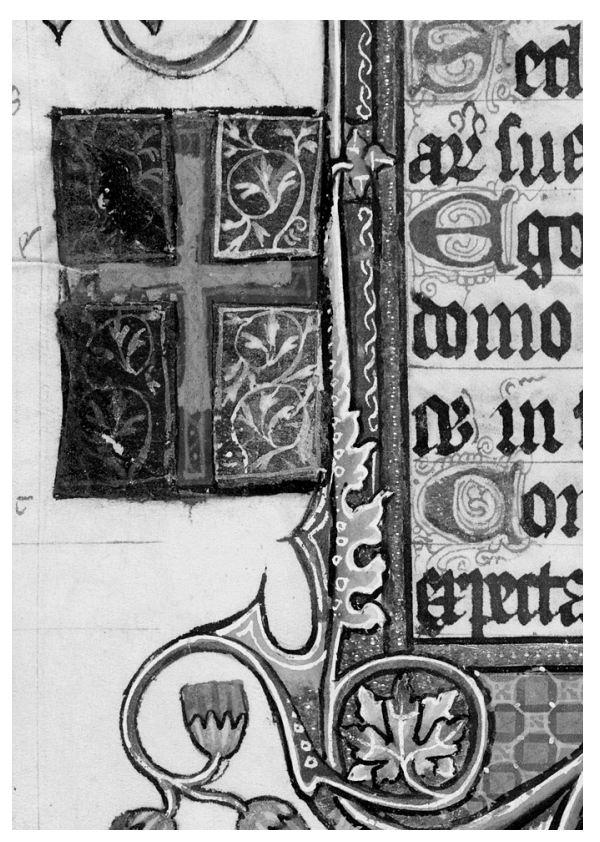

FIGURE 9. De Harcla arms, detail from left margin (text of Psalm 51); Ellesmere Psalter-Hours, fol. 85v.

More evidence that the manuscript may originally have been intended for Isabel comes from the absence of the Camville blazon. The son of Richard de Vernon/ le Franceys and Isabel de Harcla, another Richard de Vernon, married the heiress Maud (or Mathilda) de Camville in 1309. 25 The importance of Maud's inheritance to later generations of Vernons is attested by the inclusion of the Camville blazon (vert three lions passant argent armed and langued gules) in the early Tudor tomb monuments at Tong Church, in western Shropshire, where according to Heather Gilderdale Scott, "Camville connections went some way toward substantiating" the Vernon family's claims to longstanding aristocratic status "by suggesting the extent of the family's landed interests." 26 Maud's own seal impaled her husband's bearing with her father's, as a charter of 1324 attests. ${ }^{27}$ Had the Ellesmere Psalter-Hours been intended for Maud, surely her family's

my queries with detailed descriptions of the stone and its inscription. The motif, he writes, is "more like a broadsword rather than a cross, which is sprouting elaborate and somewhat detailed flowery growth"; personal communication, June 18, 2010. Unfortunately, there does not seem to be any information relating to the personal arms of Gilbert le Franceys or his father, John le Franceys, despite avid attention to the question of le Franceys genealogy and heraldry by Aaron David Weld French, Index Armorial to an Emblazoned Manuscript of the Surname of French, Franc, Francois, Frene and Other, both British and Foreign (1892; repr., 2009).

25. G. E. Cockayne with Vicary Gibbs and H. A. Doubleday, Complete Peerage of England, Scotland, Ireland, Great Britain, and the United Kingdom, extant, extinct, or dormant, 2nd ed., 12 vols. (London, 1910), 5:4.

26. Heather Gilderdale Scott, “'this little Westminster': The Chantry-Chapel of Sir Henry Vernon at Tong, Shropshire," Journal of the British Archaeological Association 158 (2005): 74.

27. Ragg, "Maud's Meaburn," 335n. 
blazon would have been included; it even seems likely that her mother-in-law, Isabel de Harcla, would have included the Camville blazon in her own book, given the coup represented by the marriage of her only son to such an heiress. This points to a very early date for the Psalter, before the marriage in 1309. Meanwhile, it is noted on the first page of the calendar that Maud's daughter, Isabel de Vernon, gave the manuscript to the nuns of the Cistercian priory of Hampole, in Yorkshire, suggesting that she had inherited her grandmother's prayerbook. ${ }^{28}$ Isabel de Vernon, who married Lord Richard de Stafford, younger brother of Earl Ralph de Stafford (1301-1372), embodied the Vernon family's aristocratic ambitions in this period of political unrest.

The Vernons' fortunes were entangled with those of other such ambitious families, including the Dacres, a tireless band of self-promoters who made such a success of themselves that they were still remembered, in Walter Scott's "Lay of the Last Minstrel," as a "hardy race" springing from a fearless, crusading ancestor. ${ }^{29}$ The Dacre blazon, gules three escallops argent, appears prominently in the manuscript on folio $73 \mathrm{~V}$ at Psalm 38, accompanied by what seems to be a variant form (per pale gules and argent three escallops countercharged), which recurs on folio $175 \mathrm{v}$, above the portrait of a lady at prayer in the initial to the Canticles. The Dacres were, like the Vernons only more so, a knightly family busy increasing their land holdings and social status through alliance with the Lords Ordainer (particularly Thomas, Earl of Lancaster), usefulness in the Scots campaign, and marriage. ${ }^{30}$ They may have had family ties to the Vernons; at some point in the thirteenth century, Ralph, Baron Vernon of Shipbrook (of the senior line of the Vernon clan) married a Mary Dacre. The date of this union is uncertain mostly because of confusion about Baron Vernon's life span. According to a legend already current in the sixteenth century, he lived to be $150 .{ }^{31}$ But perhaps more than any familial relation, it is the political affinity of the two families, and the Vernon desire to emulate the Dacres in their successful social climbing, that are indicated by the inclusion of the Dacre blazon in the Ellesmere Psalter.

Recent work on the deployment of heraldry in English fourteenth-century church glass has supported the view that "the sheer fact of neighborhood led inevitably to various forms of association, some of them largely hidden from us." 32 The importance of heraldic display to establishing the class identity of members of the non-noble but upwardly aspiring knightly families is evident in many of the manuscripts to which the Ellesmere Psalter-Hours is most closely linked-notably the Pabenham-Clifford Hours-and as Kathryn Smith has noted of the De Bois Hours (Morgan Library,

28. "Domina Issabella de vernun dedit istud psalterium conventi de hanpul. Qui alienavit excomunicatus est"; fol. 36 .

29. "The Lay of the Last Minstrel," in Poetical Works of Sir Walter Scott, bart. (New York, 1843), canto 14, p. 52.

30. An excellent account of the Dacre family's rise is to be found in Eleanor Searle, "Housed in Abbeys: the Dacres of Cumberland and Sussex, Part I: The Early Dacres and Lanercost Priory," Huntington Library Quarterly 57 (1994): 152-65.

31. Robert Glover et al., The Visitation of Cheshire in the Year 1580 (London, 1882), 230; "Radulphus de Vernon Senior: qui vixit 150 annos."

32. Peter Coss, "Knighthood, Heraldry, and Social Exclusion," in Heraldry, Pageantry, and Social Display in Medieval England, ed. Peter Coss and Maurice Keen (Woodbridge, U.K., 2002), 58. 
MS M. 700), executed around 1326-28, the extensive heraldic ornament "appears to present something akin to a selective, retrospective local roll comprising the family's relatives, neighbors, associates, and feudal connections, ... thus a kind of history of the Midlands De Bois family in its heyday." 33

Unsurprisingly, families of similar status that had a long history of rubbing elbows in a region - whether the midlands of the De Bois or the northwestern border country of the Vernons and the Dacres - tended to be entwined in histories of kinship, obligation, and shared experience that are difficult to trace clearly in the historical record. For example, the Vernons of Harlastons' baronial neighbors, the Marmions of Tamworth Castle, are suggestively evoked by the presence of the blazon, argent a sword in bend sable, the arms of Kilpec, which had come into the Marmion inheritance through marriage in the mid-thirteenth century. These appear next to what may be the portrait of the book's owner on folio $175 \mathrm{v}$. By the 1310s, the Marmions consisted of a group of female heirs, and the family's hereditary office of Champions of England had passed to an Alexander de Freville, married to a daughter of one of the heiresses. 34 Despite the proximity of the Marmion blazon to the portrait-like image in the initial, there is nothing to suggest that the Vernons and Marmions intermarried in the late thirteenth or early fourteenth centuries. But as neighbors and adherents of the same political faction - the men of each family would have been companions in arms during the long years of war and depredation that marked the period during which the Ellesmere Psalter took shape-there were no doubt ties of obligation and perhaps something like friendship between them.

The heraldic presence of other families may also indicate feudal ties: for example, the Clifford blazon (differenced with bezants), checky azure and or, a fess gules, three bezants argent, appears alone on folio 129v, beside the opening text of Psalm 97.35 As several legal transactions of the period attest, Richard de Vernon held some of his estates in fief from Isabel de Clifford. Isabel was a noble heiress and widow who exercised in her own right the authority of the sheriff of Westmorland, an office she had inherited from her father, Roger de Veteripont (or Vipont); most significantly, in 1286 she intervened on behalf of her tenants, Richard de Vernon and Michael de Harcla, who had been taken into custody by the bailiffs of Appleby as accessories to the murder of a neighbor (not a Clifford tenant), Nicholas de Hastings. ${ }^{36}$ From the de Vernon/ de Harcla point of view, Isabel's insistence on having the trial take place before a royal

33. Smith, Art, Identity, and Devotion in Fourteenth-Century England, 31.

34. William Page and Louis Francis Salzman, Victoria History of the Counties of England: Warwick (London, 1947), 156.

35. The Clifford of Skipton charge also appears in the Pabenham-Clifford Hours, which commemorates the marriage of Joan Clifford of Frampton to John de Pabenham. See J. A. Goodall, "Heraldry in the Decoration of English Medieval Manuscripts," Antiquaries' Journal 77 (1997): 181.

36. A full account of the murder and subsequent legal proceedings is found in Frederick Ragg, "Mauld's Meaburn, and le Fraunceys and de Hastings," Transactions of the Cumberland and Westmorland Antiquarian and Archeological Society, n.s., 11 (1911):321-41. For a discussion of Isabel's extraordinary assertiveness in her exercise of public authority, see Douglas Jansen, "Women and Public Authority in the Thirteenth Century," Queens, Regents, and Potentates, Women of Power 1, ed. Theresa Vann (Cambridge, 1993), 91-106. 
justice was a godsend. It led to opportunities to pack the jury with sympathetic friends and family members, and unsurprisingly the two men were acquitted. Isabel died in 1292, but the memory of her intervention would have left a deep impression on the young couple, and her son, Robert de Clifford, inherited both her estates and her patronage relationship with her tenants. All this makes the placement of the Clifford arms interesting: just next to the words "justiciam" and "veritatis," which may be hopeful talismans for lordly justice and honesty, or they may be memorials to Isabel's vital intervention at a moment when the family's fortunes hung in the balance. Also suggestive of the singular affinity expressed by the Clifford arms here, this is the only instance in the manuscript where a ferial initial has just one, rather than two, heraldic companions. Elsewhere, though the logic is not particularly clear, the bearings seem to be grouped by type: for example, the pairing of the two versions of the de Vernon arms, or that of the two variants on the Dacre charge.

After 1315, when Rannulf Dacre kidnapped and married Margaret de Multon, the presumptive bride of the seven-year-old grandson of Isabel de Clifford, cordial relations between the Cliffords and the Dacres would have been unlikely-and the Vernons may have been just as unlikely to proclaim both as their friends and allies. Stronger evidence that the Psalter predates 1314 comes from the presence on folio 97 of the blazon of Adam de Gordon, gules, three fleurs de lys argent. 37 De Gordon was a Scots marcher lord who had, for personal reasons, taken the English part in the early years of the fourteenth century, but who after the disaster at Bannockburn changed sides again and joined himself to Robert the Bruce's cause. ${ }^{38}$ The Vernons, who had hitched their wagon to the English monarchy, were hardly likely to brag of a connection to de Gordon after his change of allegiance, and so it is almost certain that the manuscript was complete, at least in the Psalter portion, prior to Bannockburn and the Dacre-Clifford dispute in 1314-15.

Another heraldic indication of the degree to which Richard de Vernon and Isabel de Harcla were enmeshed in the concerns of the Cliffords is the presence of the arms of John de Saint Owen, a Herefordshire knight probably connected to Gilbert de Clare, the Earl of Gloucester (one of the Lords Ordainer): these, barry of six gules and or, appear at the top of the same folio as de Gordon's blazon, next to the historiated initial for Psalm 68.39 John de Saint Owen's connection to the Clares is clear; not only did he appear in the retinue of the Earl of Gloucester at the Dunstable Tournament in 1309, but also his daughter, Joan, married Richard, the natural son of Richard of Cornwall, King John's second son, while Richard's legitimate half-brother, Edmund

37. Joseph Foster, Some Feudal Coats of Arms from Heraldic Rolls, 1298-1418 (London and Oxford, 1902), 113. The charge appears on the St. George (British Library, MSS Harley 246, 6137, 6589) and Arden (British Library, MS Add. 4965) rolls.

38. Oxford Dictionary of National Biography, "Gordon family (per. c.1300-c.140o)," by Simon C. Appleyard (http://www.oxforddnb.com/view/article/54209, accessed November 17, 2010).

39. Foster, Some Feudal Coats of Arms, 217. The charge appears in the St. George roll, and as discussed in A. Tomkinson, "Retinues at the Tournament of Dunstable, 1309," English Historical Review 74 (1959): 73. 
of Cornwall, was married to Margaret of Clare. The Vernon connection lies in their feudal relationship to the Cliffords; Robert de Clifford was fostered by Gilbert of Clare and served him loyally, even dying beside him on the battlefield at Bannockburn in $1314.4^{\circ}$ This web of associations may have meant that Richard de Vernon and John de Saint Owen passed considerable time in one another's company around 1310, perhaps alongside Adam de Gordon-here one can only speculate that the inclusion of the de Saint Owen and de Gordon arms marks some particular friendship or allegiance between these men.

Two remaining escutcheons, on folio 113 at Psalm 95, remain unidentified. The upper escutcheon bears lozengy or and gules, a canton sable, a cost sable over all, and the lower bears argent, two chevrons sable between two roses gules, and neither of these is clearly associated with any name in the early fourteenth century, to my knowledge. The first is strongly suggestive, however, of a Neville connection, the basic charge for Neville being lozengy or and gules, differenced variously; in particular, a canton ermine appears on the arms of Sir Geoffrey de Neville and his descendants. The Nevilles were very much mixed up in the affairs of the North, where they, like the Vernons, held the majority of their lands. Sometime prior to 1339, William de Dacre (son of the kidnapped Margaret de Multon and Rannulf de Dacre) married a daughter of Ralph de Neville, yet another indication of the way in which all of these families were linked and cross-linked through marriage, inheritance, feudal obligations, and political and personal affinity. As for the argent, two chevrons sable between two roses gules, it is otherwise unattested.

As Michel Pastoureau has repeatedly pointed out, heraldry in its original context was as much about imagination as documentation. ${ }^{41}$ This is borne out by the first charges that appear, on folio 42, in the frame of the Beatus initial at the beginning of the Psalter, both referring to English royal dynasties. The gules, three lions passant or of Plantagenet England presumably points to the reigning monarch (Edward II), and the azure a cross patonce between five martlets or indicates another Edward, the Confessor. Although the historical Edward the Confessor was extremely unlikely to have borne arms (a practice that emerged only late in the twelfth century, over a century after his demise), this charge (or a version with four birds instead of five) was assigned to him in several thirteenth- and fourteenth-century rolls of arms, including Segar's Roll and Sir William le Neve's Roll. ${ }^{22}$

Does the presence of royal heraldic blazons, one historical and the other legendary, imply royal family connections for the original owners or patrons of the book? This is possible, of course, but in the event seems unlikely—-the manuscript simply isn't as polished or luxurious as contemporary books produced for the royal family, such as the Queen Mary Psalter, the Ancient 6 Psalter, and the (somewhat later) Taymouth

40. For Robert's relationship to the Earl of Gloucester, see Jansen, "Women and Public Authority," 95. For the English dead at Bannockburn, see David Cornell, The Battle of Bannockburn: The Triumph of Robert the Bruce (New Haven, Conn., 2009), 261-63, where he compiles all the archival lists and notes those names that appear on multiple lists.

41. Notably, M. Pastoureau, Traité d'héraldique, 3rd ed. (Paris, 1997), 258-61.

42. See G. J. Brault, The Rolls of Arms of Edward I, 1272-1307 (New York, 1997), 148. 
Hours. 43 Royal arms often appeared in manuscripts for non-royal patrons with no lineal ties to the ruling dynasty; this is the case with the Pabenham-Clifford Hours, probably the closest relative of the Ellesmere Psalter-Hours. The inclusion of the fictional blazon of Edward the Confessor points to a more ideologically complex motivation for the heraldic decorations. David the Psalmist was also David the King; it was almost a requirement that medieval kings model themselves on this exemplary monarch, and the reign of Edward II of England (during which the Psalter portion of the manuscript was most likely made) was no different in this respect. 44 The inclusion of the current royal arms would strengthen this association, while the presence of the sainted Anglo-Saxon king's escutcheon would underscore that this sacred aspect of kingship was endemic to the English throne. In addition, at least since the time of Henry III, the Plantagenet monarchs had been concerned to present a historical view that stressed continuity between the Anglo-Saxon and Norman periods, and this ideological vein was still being mined well into the fourteenth century, as Paul Binski demonstrated in his discussion of the cult of Saint Edward the Confessor at Westminster Abbey. 45 In short, the presence of the royal blazons in the Ellesmere Psalter-Hours may indicate the patron or owner's loyalty to the ideal of the English monarch, perhaps an ideal perceived as being at odds with the current situation, given Edward II's unpopularity in the North in the early 1310 s.

The foregoing description of the Ellesmere Psalter-Hours has been intended to give as clear a picture as possible of the book's origins and character. In summary, I would agree with earlier assessments that place the manuscript's illuminator(s) in East Anglia and its primary owners in Shropshire, though with the addition of their deep connections to Cumbria and the Scots borderlands. Indeed, I would go so far as to say that it seems likely that Isabel de Harcla and Robert de Vernon were the original owners of the Psalter portion, and that from them it passed to their granddaughter, Isabel de Vernon. Whether it was the first or second Isabel, or some other party, who added the Hours, it seems likely that the two interdependent pieces of the current manuscript went to Haddington Priory together around the middle of the fourteenth century. I suspect that Isabel de Vernon died around 1348-49, as she seems to have vanished from the historical record by the early 1350 s, when her husband remarried, and she wasn't married before 1337; meanwhile, Isabel de Harcla was still alive and litigious in 1342, when she would have been closing in on eighty years old. ${ }^{6}$ This account leaves

43. See Anne Stanton, The Queen Mary Psalter: A Study of Affect and Audience (Philadelphia, 2001), 23-25; and "Isabelle of France and Her Manuscripts," in Capetian Women, ed. Kathleen Nolan (New York, 2003), 225-52.

44. As Jochen Burgtof has pointed out, Edward's critics even used this expectation against him, comparing him to Solomon's unsatisfactory son, Rehoboam, who would have been understood in the fourteenth century as a sodomite, an accusation also leveled against Edward; Burgtof, "'With his life, my joyes began and ended': Piers Gaveston and King Edward II of England Revisited," FourteenthCentury England 5 (2000): 46.

45. Paul Binski, Westminster Abbey and the Plantagenets: Kingship and the Representation of Power, 1200-1400 (New Haven, Conn., 1995), 52-89.

46. Ragg, "Maud's Meaburn," 335. 
many questions unanswered. The most pressing of them is how the subtle shift between text-image relations in the Psalter portion and those in the later Hours section speaks to the changing status of French as an elite language and to the gendered construction of personal devotion in the period between about 1310 and 1330 . For just as the superabundance of heraldic imagery in the earlier Psalter portion speaks to the social identity and upwardly mobile aspirations of the book's owner or owners, so the French-Latin bilingualism of the later Hours also signals a desire to identify with elite status and to emulate the sophisticated devotional culture of French-speaking aristocratic and royal courts.

\section{Text and Image, Vernacularity and Invention}

The first part of the Ellesmere Psalter-Hours contains a number of intriguing textual oddities that more than compensate for its inferior scribal quality compared to the attached Psalter. Anglo-Norman or Latin rubrics introduce most of the sections of the text; sometimes the Latin is very strange, as in the rubric for the Hours of the Virgin, which designates the office as "cotidiano" - or daily—not really a standard locution but, it seems to me, a kind of pidgin of Latin and Middle English (the Middle English "cotidian" plus the latinate ending "-o"). The texts themselves are a mix of Latin and AngloNorman. The Office of the Passion is fairly unexceptional, but what follows is very unusual. The Short Hours of the Cross was historically attributed to Pope John XXII (r. 1316-34), but Abbé Leroquais observed that the text in fact went back to the eleventh century and appeared in at least one thirteenth-century Book of Hours from France, 47 while Sandler opined that it was probably the case that John XXII revised the office and was responsible for the indulgence attached to its recitation, which spurred its popularity. Unfortunately, as she notes, the date at which such an indulgence was granted cannot be determined..$^{8}$ In any case, the text remained very rare until later in the fourteenth century, and the witness of the Ellesmere Psalter-Hours is one of the earlier examples from England, if indeed it belongs to the middle of the 1320s, as the evidence of the painting style suggests. Furthermore, with its French rubrics and its accompanying Anglo-Norman French verses, its presentation seems especially adapted to a lay reader. The Anglo-Norman text itself is even rarer than the Latin. A loose translation of the Latin quatrains of the Short Hours of the Cross, the version found in the Ellesmere Psalter-Hours is one of only five manuscript witnesses, dated between the last decade of the thirteenth century and the first quarter of the fifteenth. 49 It is the

47. Leroquais, Les Livres d'Heures manuscrits, xxvi. "Mais il conveient d’observer que dès la fin du XIIIe siècle, on trouve l'office de la Passion dans les Heures à l'usage de Thérouanne (lat. 14284, fo. 1-41)." 48. Sandler, "An Early Fourteenth-Century Psalter," 72.

49. Ruth Dean, Anglo-Norman Literature: A Guide to Texts and Manuscripts (London, 1999), no. 966, p. 483. The other witnesses include two miscellaneous rolls (Public Record Office [London], C47/34/16 dorse, and Shropshire Records and Research Centre [Shrewsbury], 12692 [not 12962, as in Dean], face m. 2- the only thirteenth-century witness); the DuBois Hours (Morgan Library, MS M.70o), in which the text is not illustrated or chained with the Latin office; and an unillustrated devotional and pedagogical compendium of ca. 1420 that includes texts in French, English, and Latin (Bodleian Library, MS Bodl. 9 [1851], fols. 37v-38v). 
only example in which Latin and Anglo-Norman text are intercalated and paired with a program of illumination, and it is also the only example in which the rubric specifically mentions that the recitation of the Hours in French will result in the granting of indulgence. While other Continental French versions of the Short Hours of the Cross and one version in Provençal are known, none of these seems to predate the Anglo-Norman version, and all are found in later fourteenth- and fifteenth-century manuscripts. 50

This unusual text follows its Latin model in putting the devotional observance into verse, but it is not a direct translation, rather a paraphrase, introducing a note of lyric sweetness. Where the Latin text begins, baldly, Patris sapientia veritas divina / Deus homo captus est hora matutina, the Anglo-Norman opens, Sire Jesu ky par toun doux playser / a houre de matynes voylez suffrer (Lord Jesus, who by your sweet pleasure / wished to suffer at the hour of matins). The Father, holy wisdom, and divine truth are replaced by a more poignant and pleasingly paradoxical formulation, in which it is Jesus' "sweet pleasure" to suffer for mankind. Whether one applauds the scansion and rhyme of the couplets or not, their sensitivity to the emotive tone of devotion to the Cross seems greater than that of the Latin upon which they are based. The plaintive juxtaposition of "playser" and "suffrer" found in the opening couplet is mirrored in the larger structure of each huitain. Beginning with a vivid, if brief, evocation of one of the torments of Christ during the Passion, each stanza turns on the phrase, Cele houre memes (This very hour), from Christ's human suffering to his divine Resurrection and its implications for the devotee. Thus, at Matins, the second half of the stanza rejoices, Cele houre memes de mort levastres / Et nos de payne deliveraustes (This very hour, you arose from death / and delivered us from pain), before pleading with Christ to pardon the devotee's sins and to give the devotee patience in tribulation.

The Anglo-Norman text's dramatic swings between pathos and exultation evoke the contemporary vogue in devotional practice for high affect and for a focus on the bodily sufferings of Christ, such as those found in the pseudo-Bonaventuran Meditationes in Vitam Christi and, perhaps more to the point, in Edmund of Abingdon's Speculum ecclesiae (dated to 1213-14), which extended and deepened the traditional association of events from the Passion with the liturgical hours by pairing the Passion episodes nonsequentially with events from the Infancy and Resurrection narratives. ${ }^{51}$ In fact, there are distinct parallels between the Anglo-Norman text of the Short Hours of the Cross and the Speculum ecclesiae, translated in the middle of the thirteenth century into Anglo-Norman as the Mirour de seinte eglyse. ${ }^{52}$ At Prime, for example, the

50. The first to discuss the French and Provençal versions was Paul Meyer, in Daurel et Beton: Chanson de geste provençale publie pour le première fois d'après le manuscrit unique appartenant a M. A. Didot (Paris, 188o), cix-cxix. See also Arthur Långfors, "Notice du Manuscrit Français 24436 de la Bibliothèque Nationale," Romania 41 (1912): 206-46, esp. 234-36.

51. Helen Forshaw, "St. Edmund of Abingdon's Meditations before the Canonical Hours," Ephemerides liturgicae 78 (1964): 35-57.

52. Edmund of Abingdon, Mirour de Seinte Eglyse (St. Edmund of Abingdon's "Speculum Ecclesie"), Anglo-Norman Text Society Publications, vol. 40, ed. A. D. Wilshere (London, 1982), chaps. 21-27, pp. 58-72. 
Mirour advises the aspiring devotee to contemplate, first, the Jews bearing false witness against Christ, and then the harrowing of Hell and the ten appearances of Christ to his followers after his Resurrection, with particular emphasis upon the first, his meeting with Mary Magdalene. The Anglo-Norman office, much less expansive than the Mirour, condenses this program into the textual diptych of Christ brought before Pilate and the Noli me tangere:

Sire Jhesu qui a houre de prime

Devant Pilate mult felun crime

Les ieus vous diseint par envie

Et lur aperte felunie

Cele houre memes de mort levastes

A la Magdeleyne qui mult amastes

Moustrez moy, Sire, vestre face

A de ben fere moy donez grace.

(Lord Jesus, who at Prime was accused before Pilate of many terrible crimes by the Jews out of their envy and their open criminality, in that very same hour rose from death and showed himself to the Magdalene. Lord, show me your face to do me good and give me grace.) 53

Notably, the phrase "Cele houre memes," repeated at the turn of each huitain in the poem, picks up on the language of the Mirour, in which the second half of each set of meditations on the hours opens with a similar construction, for example, at Matins, "De la passion devez penser coment il estoit cele houre de la nuyt trahi de son desciple" (On the Passion, you must think about how he was betrayed by his disciple in this hour); 54 and at Prime, "De la resurrexion devez penser ke a cel' houre leva Jhesu Crist de mort a vie" (On the Resurrection you must think that at this hour Jesus Christ rose from death to life). 55 The poem could almost be construed as a kind of response to the Mirour's instructions, a succinct and pithy set of contemplative pairings that show an awareness of the much longer instructional text but seek to digest it for use in the context of the performance of hourly devotions by a layperson.

Familiarity with the Mirour would not be surprising on the part of the office's Anglo-Norman author/translator, nor on that of the early owners of the Ellesmere Hours. Twenty-three manuscripts attest to the popularity of the Mirour in French among monastic, clerical, and lay audiences conversant in Anglo-Norman in the late thirteenth and fourteenth centuries. ${ }^{6}$ Over eighty manuscripts in total, including those

53. My transcription and translation; EL $9 \mathrm{H}_{17}$, fol. 15.

54. My emphasis. Edmund of Abingdon, Mirour de Seinte Eglyse, chap. 21, p. 59. This is the "lay" version of the text. Wilshere's edition has the monastic and lay versions in parallel, which in this respect (the use of "cele houre") are very similar. I favor the lay version because it would probably have been this text that was more familiar to the original audience for the Ellesmere Psalter-Hours.

55. Ibid., chap. 22, p. 61.

56. Wilshere, "Introduction," Mirour de Seinte Eglyse, vi. 
in Latin and Middle English, survive, mostly in British collections, suggesting that the text remained popular in England right up to the Reformation. 57 Claire Donovan noticed that the iconography of the large historiated initials in the de Brailes Hours, executed around 1240, corresponds to the pairing of Infancy and Passion episodes in the Latin text of Edmund of Abingdon's Speculum Ecclesie, a very early clue to the appeal of this devotional approach for the laity..$^{8}$ More recently Anne Stanton has suggested that the Mirour influenced the pictorial organization of the Queen Mary Psalter (London, British Library, MS Royal 2. B.viii), a manuscript produced in roughly the same period as the Ellesmere Hours (1310-25); furthermore, she points to the coincidence that the Queen Mary Master also illuminated a devotional miscellany (Bibliothèque nationale, BnF ms. fr. 13342, and Bodleian, MS Douce 79) that contained the Mirour.59 In terms of the Ellesmere Hours, what this means is that some degree of intertextuality with the Mirour is more than possible, even likely. As I will demonstrate shortly, the ties between the Ellesmere Hours and other visual responses to the Mirour support this view.

But for the moment, I want to return to the way in which the Ellesmere Hours uses the subtle differences between the Latin and Anglo-Norman texts to open multiple experiential doors into devotion to the Passion and Resurrection. One difference highlighted by the placement of the Latin and Anglo-Norman versions of the office on the same pages is their relative levels of liturgical structure and formality: whereas the Latin office is sprinkled with rubrics indicating the generic nature of the highly abbreviated texts (for example, abbreviations for psalms, antiphons, and lections), the Anglo-Norman verses suffer no interruption and employ few abbreviations or Tironian notes, a scribal choice that makes them more suited to continuous reading than their Latin counterparts. The effect of this pairing of liturgically indexed Latin with poetically presented French is polyphonic; the Latin provides a kind of continuo through which the more melodic line of the verse can be woven. The terse indication of incipits in the Latin office points to what might even amount to a fugue of texts, if one can imagine holding this book open while hearing the Latin office performed aloud, one's own voice (perhaps whispered) intoning the French.

Another key difference is the way in which the abbreviations and incipits of the Latin office, along with its much less expansive treatment of the Passion episodes and its omission of the Resurrection and Infancy episodes, make it relatively emotionally flat (when the full texts referred to by the incipits are read, however, the emotional key would rise, with such texts as Psalm 6, "Domine, ne in furore"). Meanwhile, the whole structure of the Anglo-Norman poem works to heighten pathos through stark contrasts of suffering and triumph. This current of working back and forth between the most abject images of Christ's suffering and the transcendent intimacy of Christ's Incarnation and Resurrection runs through so much late thirteenth- and early fourteenth-

57. The most comprehensive study of the manuscript tradition is Speculum religiosorum; and, Speculum ecclesie, ed. Helen Forshaw, Auctores Britannici Medii Aevi, no. 3 (London, 1973).

58. Claire Donovan, The de Brailes Hours: Shaping the Book of Hours in Thirteenth-Century Oxford (Toronto and Buffalo, 1991), 69.

59. Anne Rudloff Stanton, The Queen Mary Psalter: A Study of Affect and Audience, Transactions of the American Philosophical Society, vol. 91, pt. 6 (Philadelphia, 2001), 3, 79-80. 
century devotional literature that it would be easy to characterize it simply as a symptom of "mendicant" or "affective" piety, but I think that here it can be understood more specifically.

Again, in the choice of episodes linked together at the hours, the structure of the Mirour de Seinte Eglyse is manifest. Just as at Prime, the Anglo-Norman versifier of the office follows the Mirour's lead in selecting and highlighting the sharp contrast between Christ's respective meetings with Pilate and Mary Magdalene, at Terce the Mirour's pairing of Flagellation and Pentecost is repeated. Other places where the two texts resonate include Nones, when both direct the reader's attention to Christ commending his soul to God the Father upon the Cross and to the Ascension; Vespers, when both focus on Joseph of Arimathea's role in the post mortem care of Christ's body and on the Last Supper as the institution of the Eucharist; and Compline, where the Entombment and the Agony and the Garden are featured. The only place where the two texts diverge is at Sext. Here, the focus of the Mirour is on the humanity of Christ in a theological vein, and while the Annunciation and Crucifixion are briefly mentioned, they appear only to anchor the more abstract interests of the devotion. Edmund instructs the devotee, "De l'anunnciacion devez penser de la misericorde Nostre Seignur, pur quey il volyt home devenir, e mort soeffrir pur nous en sa humanité, puis ke en autre manere [nus] poet aver rechaté" (Regarding the Annunciation, you must think upon the mercy of Our Lord, for he desired to become a man and suffer death for us in his humanity, when he could have redeemed us in some other way). ${ }^{60}$ The Passion also receives a rather abstract treatment. In fact, the author, having described Jesus on the cross between the two thieves very briefly, remarks, "Ci ne say jeo quey dire" (I don't know what to say of this), a statement he then goes on to gainsay with a long excursus on the nature of Christ's pain as superior to that of all others, and on the sorrows of the Virgin.

The Short Hours of the Cross, however, boils this meditation on Christ's humanity down to some very bodily imagery. The thesis, as it were, is the nailing of Christ's hands and feet to the wood of the cross. This seems a creative response to the less specific discussion of Christ's physical agony found in the Mirour; what could be a more painful mental image than that of the nails being driven into hands and feet? And as for the Mirour's instruction to dwell upon the Annunciation as an example of Christ's mercy, the poet seems more interested in Mary's mercy than that of Christ, tying the Incarnation in her virgin body to the redemption of the devotee's sins. Indeed, at this critical, impassioned moment, the verse slips into what looks to be a line of Middle English: "Cele houre meimes de seinte Marie / Thar preistes virgine vereye / Pur cele anunciatioun / De mes pecchez mey donez pardoun." (This very hour, of Holy Mary, [priceless?], true virgin, it needs [that] by this Annunciation give me pardon for my sins). ${ }^{61}$ The shift into English, so unexpected, might actually be in itself a reflection of the Mirour, for in the meditation on Sext in that text, the suffering of the Virgin before the Cross is illustrated with a variety of biblical passages, and then a quotation of

6o. Edmund of Abingdon, Mirour, chap. 24, pp. 4-7, 65. My translation.

61. I am indebted to Christine Cooper-Rompato for help with deciphering this difficult Middle English phrase. 
a short Middle English lyric, the now much-anthologized "Nou goth sunne under wode," which is in fact known to modern editors only from its appearance in the Mirour. ${ }^{62}$

This slippage from Anglo-Norman into Middle English (also evident in the Latin rubric that uses the macaronic "cotidiano") is telling, in terms of the context for the Ellesmere Psalter-Hours' production and use. For, as Susan Crane has noted, as early as 1200 French had ceased to be a "natural" or primary language for even the majority of the elite in England, and by 1240, "Anglo-Norman was appropriate to women in its inferiority to Latin, but it was, at the same time an elite language in contrast to English." 63 Given the evidence of Isabel de Harcla's and Isabel de Vernon's probable ownership of the manuscript, it is reasonable to suggest that the book was conceived with a feminine, elite audience in mind. Further, as Crane also points out, aristocratic women's particular responsibility for French language instruction to their offspring was explicitly articulated by a series of treatises that circulated from the midthirteenth century onward. ${ }^{64}$ Not coincidentally, one of the later witnesses in the manuscript tradition of the Anglo-Norman octosyllabic Short Hours of the Cross is found in a fifteenth-century miscellany that includes-in addition to a number of other devotional texts in French, English, and Latin-several short works that deal with puericulture (including instruction in literacy and language), and series of French prayers with feminine endings, suggesting a female destinaire for the compendium. ${ }^{65}$ Similarly, the manuscript tradition of the Mirour strongly indicates that whereas the original Latin text was composed for men in religious orders, the AngloNorman translation was often aimed at a feminine reader/listener. ${ }^{66}$

\section{Words Mirroring Pictures, Picturing the Mirour}

The hiccup at Sext in the otherwise tight relationship between the Ellesmere AngloNorman Short Hours of the Cross and the Mirour would have to be explained as the discomfiture of the later author with the abstraction of the Mirour's treatment of Incarnation and left at that, if it were not for the pictorial element of the text. The diptych images that occupy the lower third of each page of the paired Latin/Anglo-Norman office provide an important clue to the origins of this unique constellation of multilingual text and image. For, surprisingly, there is a visual precedent for this otherwise unprecedented ensemble. It is found in the Nuremberg Hours, that strange, hybrid manuscript conventionally attributed to the Parisian painter Master Honoré but clearly written for an Anglo-Norman audience. ${ }^{67}$ The paintings, including twelve full-page

62. Carleton Brown, A Register of Middle English Religious and Didactic Verse, 2 vols. (Oxford, 1916), 1:310, 376.

63. Susan Crane, "Social Aspects of Bilingualism in the Thirteenth Century," in Thirteenth Century England VI, ed. Michael Prestwich, Richard Britnell, and Robin Frame (Woodbridge, U.K., 1997),

$103-115$ at 106.

64. Ibid., 106-7.

65. Bodleian Library, ms. Bodl. 9 (1851), ca. 1420; see A Summary Catalogue, vol. 2, pt. 1 (1922), 84. 66. Wilshere, "Introduction," xx.

67. Eleanor Simmons, Les Heures de Nuremberg: Reproduction intégrale du calendrier et des images du manuscrit Solger $4.4^{\circ}$ de la Stadtbibliothek de Nuremberg, trans. Charles Scheel (Paris, 1994). Honoré's 
framed miniatures and six large historiated initials, have many traits that mark them as the work of a Parisian artist: perhaps most notably the subtle modeling of flesh tones and the elegant, plastic treatment of drapery. But the text and iconography of the Nuremberg Hours indicate English use, including images of Edward the Confessor and the Mercian princess-martyr Osgyth, mention in the calendar of four further AngloSaxon saints (all the focus of particular veneration by Plantagenet monarchs), and the naming of numerous English saints (at the expense of non-English saints) in the litany.

Dated to the 1290 os (but before 1297), the Nuremberg Hours is a far more luxurious production than the Ellesmere Psalter-Hours; Eleanor Simmons has argued convincingly that it was probably originally a joint commission conceived by the Anglo-French power couple, Edmond of Lancaster (brother of Edward I) and Blanche of Artois (mother-in-law of Philip the Fair through Jeanne de Navarre, the daughter of her first marriage), with some input from Marie of Brabant, Philip's stepmother. Simmons situates the manuscript at the crux of the negotiations between Philip and Edward that took place in 1293-94 concerning Edward's proposed marriage to one of Philip's half-sisters, either Blanche or Marguerite. The manuscript, she argues, would then have been intended for this princess (in her view, Blanche), though it was not actually given to a French-born English royal bride until Charles VI offered it to Catherine, upon her marriage to Henry V in 1420 , as an inscription on a back flyleaf indicates. ${ }^{68}$

The Nuremberg Hours, then, is most likely a royal manuscript, produced through the collaboration of members of both the French and English royal families at a time when relations between the two crowns were fraught; the marriage first proposed in 1293 was not taken up again until 1298, when negotiations were reopened and Edward I's marriage to Philip's half-sister, Marguerite, was finally sealed. The Ellesmere Psalter-Hours, by contrast, belongs to a far less lofty sphere. Yet the manuscripts share one important feature, and that is their mutual engagement with the Mirour de Seinte Eglyse. As was first noted by Nigel Morgan, the non-sequential and linked treatment of scenes from the Infancy, Passion, and Resurrection in the Office of the Virgin in the Nuremberg Hours can be understood to illustrate directly the Mirour's prescriptions for meditations linked to the canonical hours. ${ }^{6} 9$ Set beside the Nuremberg cycle, the Ellesmere diptychs show more than a coincidental similarity. At the iconographic level, Table 1 demonstrates the close parity between the two series of illuminations - the Ellesmere example being less expansive, in keeping with the more succinct character of the Short Hours text. Shared details such as the glove on Pilate's left hand, the knotted turban of Mary Magdalene (fig. 10), and the elaborate drapery over Joseph of Arimathea's arm and hand in the Deposition (fig. 12) show that both

authorship is usually accepted. I am inclined to agree, however, with Ellen Kosmer's assessment of the "Honore question" - that the documentary evidence is not sufficient to support the ascription of this, or any number of other important manuscripts usually associated with the name, to the same artist whose name appears in the Tours Decretals of Gratian (Bibl. Mun. [Tours], MS 558). See Kosmer,

“Master Honoré: A Reconsideration of the Documents," Gesta 14 (1975): 63-68.

68. Simmons, Les Heures de Nuremberg, 39-44.

69. Nigel Morgan, "Response to Eleanor Greenhill," in Europäische Kunst um 13oo, vol. 6, ed. Gerhardt Schmidt and Elisabeth Liskar (Vienna, 1986), 95-99. 
Table 1. Comparative Iconography of EL $9 \mathrm{H}_{17}$ and Nuremberg Hours

\begin{tabular}{|c|c|c|}
\hline & $\mathrm{EL}_{9} \mathrm{H}_{17}$ & Solger $4.4^{\circ}$ \\
\hline Matins & Arrest/Harrowing & Dormition of the Virgin (initial) \\
\hline \multirow[t]{2}{*}{ Lauds } & [included with matins] & Nativity/Annunciation to \\
\hline & & Shepherds/Arrest/Christ with Annas \\
\hline \multirow[t]{2}{*}{ Prime } & Christ before Caiphas/ & Christ before Caiphas/Christ \\
\hline & Noli me tangere & Mocked/Harrowing/Noli me tangere \\
\hline Terce & Flagellation/Pentecost & Flagellation/Pentecost \\
\hline \multirow[t]{2}{*}{ Sext } & Nailing to the Cross/ & Annunciation/Visitation/via \\
\hline & Annunciation & $\begin{array}{l}\text { Crucis/Christ stripped before } \\
\text { crucifixion }\end{array}$ \\
\hline None & Crucifixion/Ascension & Crucifixion/Ascension \\
\hline Vespers & Deposition/Last Supper & Deposition/Last Supper \\
\hline Compline & Entombment/Gethsemane & Entombment/Gethsemane \\
\hline
\end{tabular}

Iconographic subjects indicated in bold are shared between the Ellesmere and Nuremberg manuscripts.

artists were working from a common repertoire, and one not necessarily universally shared by either French or English illuminators of the period. Given the Ellesmere Psalter-Hours' ambitious engagement with francophone devotion, it is not surprising to see an awareness of French work in the paintings as well. This is not to say that the Ellesmere painter had direct contact with the Nuremberg Hours-that seems unlikely, given the latter's history-but rather that the existence of a paired Infancy and Passion pictorial cycle based on the Mirour was known to the artist and associated with highstatus French illumination. Responding, perhaps, to the book owner's self-image as a sophisticated member of the cultural elite, the artist crafted a French-flavored pictorial scheme that mimicked the kinds of imagery found in royal and courtly works.

Although working for gentry patrons, the illuminator of the Ellesmere PsalterHours was apparently a rather cosmopolitan soul, well versed in the latest fashions in devotional art both in England and on the Continent. I would even go so far as to argue that the illuminator could read and understand the French text, allowing a degree of invention to enter the visual program with the adaptation of well-worn iconography to new purpose, ramping up its emotional intensity in response to the heightened affective tone of the Anglo-Norman verses. To begin, it is clear that the artist understands the antithetical structure of the verses. Reversing longstanding iconographic conventions, the right-hand scenes in several of the diptychs read from right to left, so that at Prime, for example, Mary Magdalene approaches the risen Christ from the right (fig. 10), and at Sext, Gabriel makes his annunciation to the Virgin from the right (fig. 11). For medieval viewers, these reversals would have been attention-getters; the habit of scanning these widely represented scenes from left to right was deeply ingrained through 
their frequent appearance in church glass, sculpture, metalwork, ivory, and other media. Furthermore, the reversals help direct the pictorial movement of each panel of the diptych back toward the hinge, just as the phrase "cele houre memes" centers the literary composition. Throughout, the essential role of the miniatures is to make manifest the devotional concept of synchronicity expressed in the text but impossible to experience in the linear, diachronic nature of reading.

Like the text, the paintings emphasize contrasting affective states through structural similarities and repetition with variation. For example, at Matins the soldier arresting Christ on the left occupies the same portion of the field in roughly the same posture and gesture as Christ drawing Adam's soul from the Hellmouth on the right (fig. 10). Against the otherwise sharply contrasting compositions, this visual rhyme stands out. The proliferation of various and highly individualized faces and the press of bodies in the Arrest scene could not be more different from the pared-down Harrowing of Hell, where the usual crowd of supplicants is reduced to a few hands stretching up from the maw of the beast, leaving more room for the artist to explore the figures of Christ and Adam. In the Harrowing, the artist untangles the knot of grasping arms and hands in the Arrest and organizes a composition that leads the eye on a sharp diagonal up from Adam's free hand, through his forearm, and across Christ's chest, to terminate with the cruciform staff, which seems to point out the rubricated instructions to the devotee to recite the Pater Noster and the Ave Maria five times at each hour. This ultra-pictorial gesture is repeated in the next pair of miniatures as well, where Christ's staff leads the eye up to the name "Maria" in the text above, cross-referencing the Virgin to Mary Magdalene, who kneels to the right.

The contrasting backgrounds of the two halves of each miniature-iconic gold for the Passion scenes, diapered blue or red for the Infancy or Resurrection scenesalso correspond to the literary structure of the poems. The gold, which tends to make the figures in the foreground float free of a defined, spatial envelope and exist in a more abstract kind of space, seems well suited to the contemplative nature of the opening lines of each poem. The diapered grounds, though flat in their own way, are more continuous with the coloring of the figures. The figures, then, become more anchored to the material of the page, more present and immediate. This matches the shift in the second half of each poem, which speaks in the first person, as in "Give me pardon for my sins and patience in times of trouble," or "Lord, show me your face and do me good by giving me grace."

The artist's sensitivity to the poet's literary strategy continues throughout the series. At Compline, when the Anglo-Norman text abandons its usual contrast of Passion to Infancy or Resurrection events and instead opens by evoking Christ preaching to the apostles at the Last Supper, then turns to the entombment, beseeching aid in the name of the Holy Sepulcher, the artist adapts to the shift in literary approach (fig. 13). The redemptive scene-the entombment-appears unusually on the left against a gold ground, while the episode of suffering, expressed in the text in terms of the irony of Judas's betrayal taking place while the other apostles sat and listened to the end of 


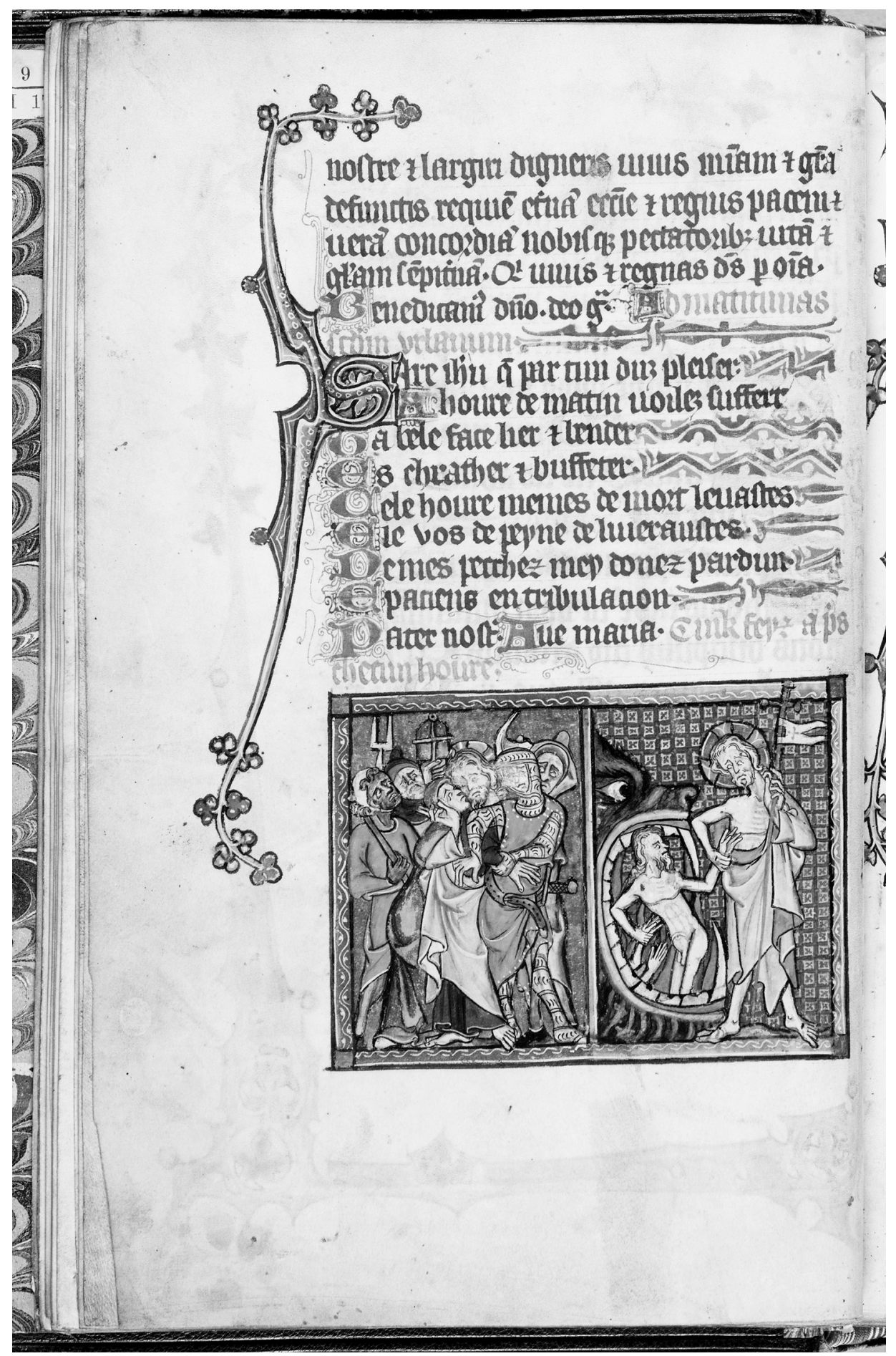

FIGURE 10. Arrest of Christ/Harrowing of Hell, Judgment of Pilate/Noli me Tangere, diptychs from Matins and Prime of the Short Hours of the Cross; Ellesmere Psalter-Hours, fols. 14V-15 (Huntington Library, EL $9 \mathrm{H} 17$ ). 


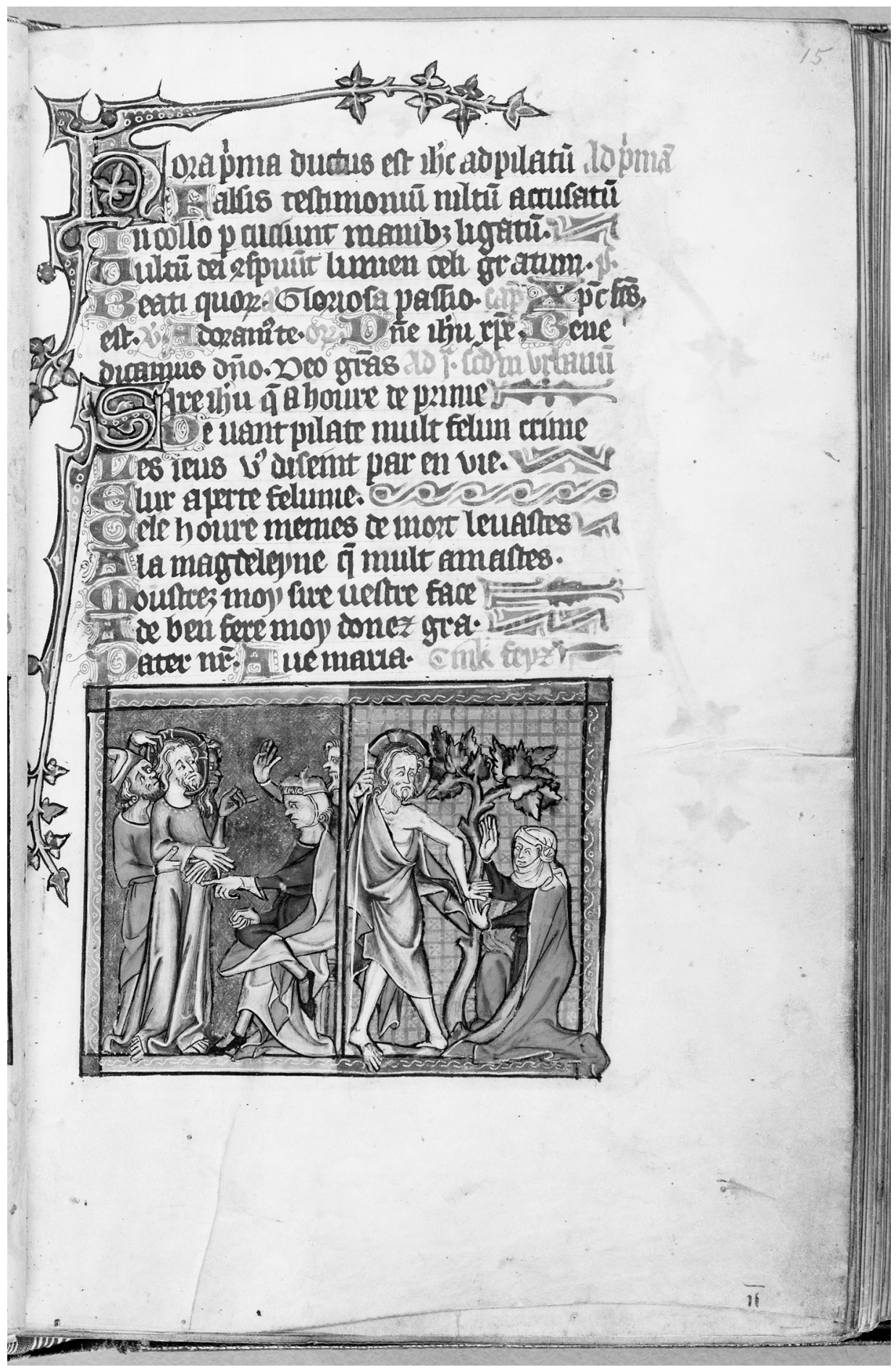




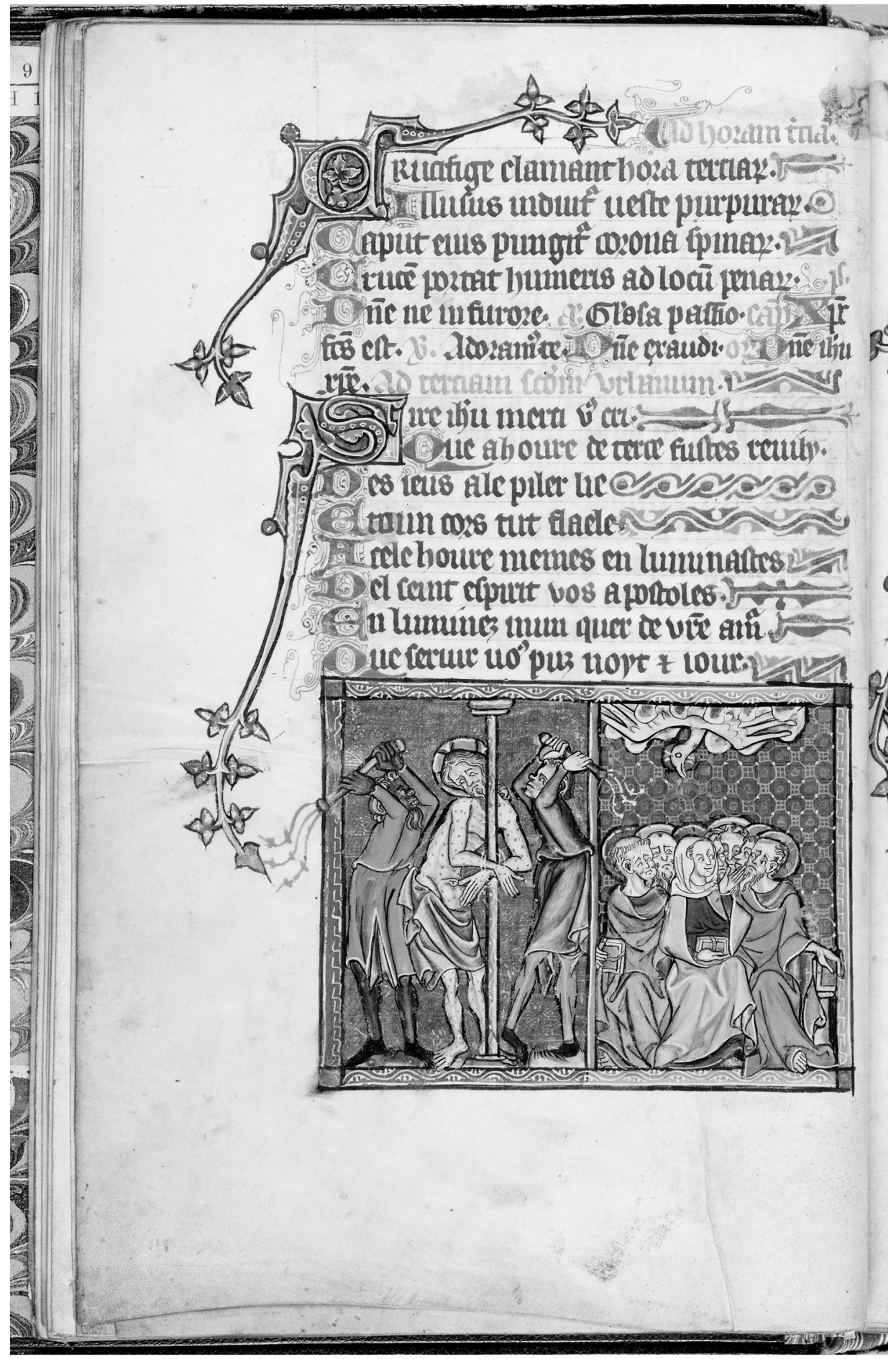

FIGURE 11. Flagellation/Pentecost, Nailing to the Cross/Annunciation, diptychs from Tierce and Sext of the Short Hours of the Cross; Ellesmere Psalter-Hours, fols. 15V-16. 


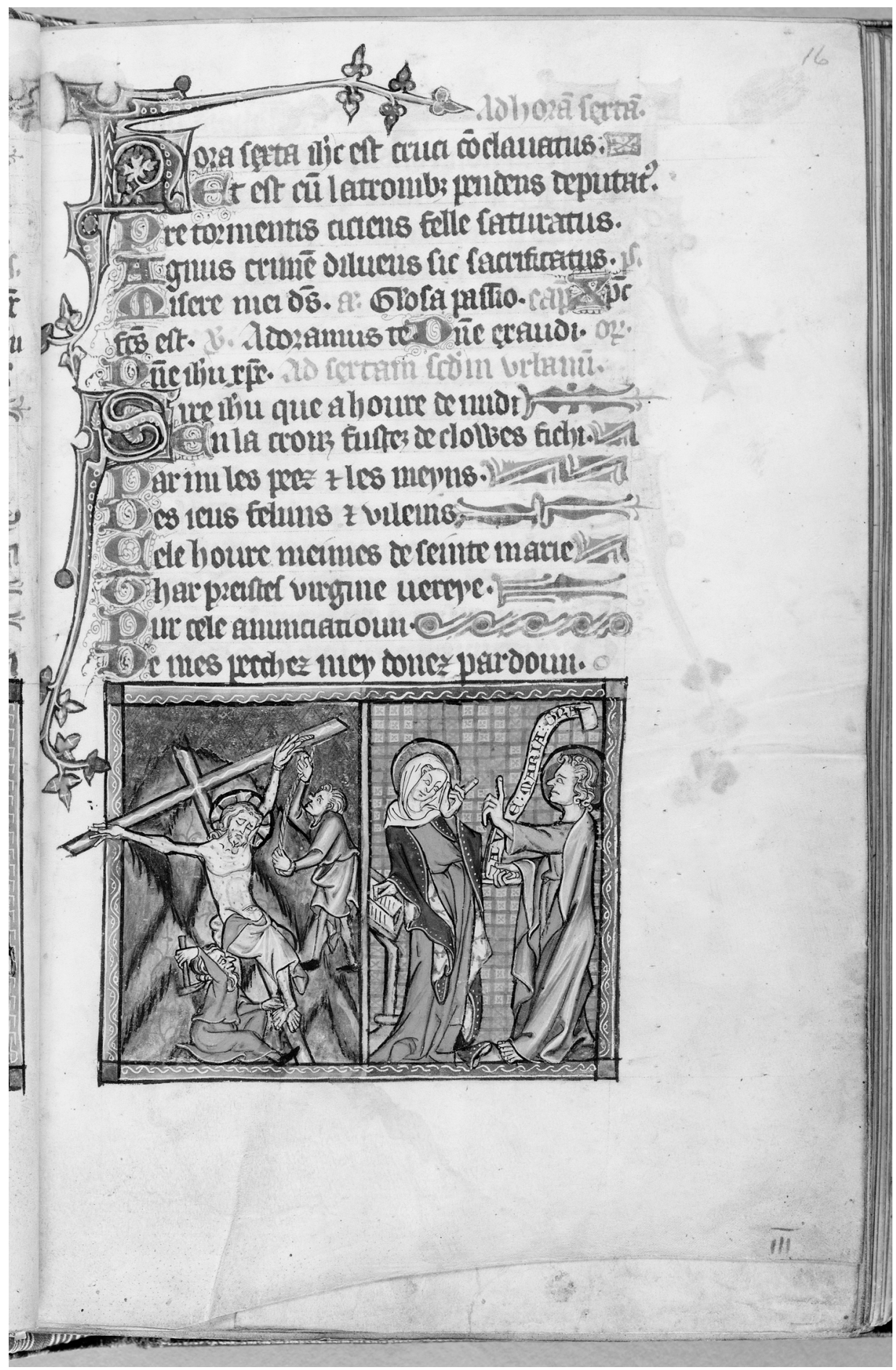




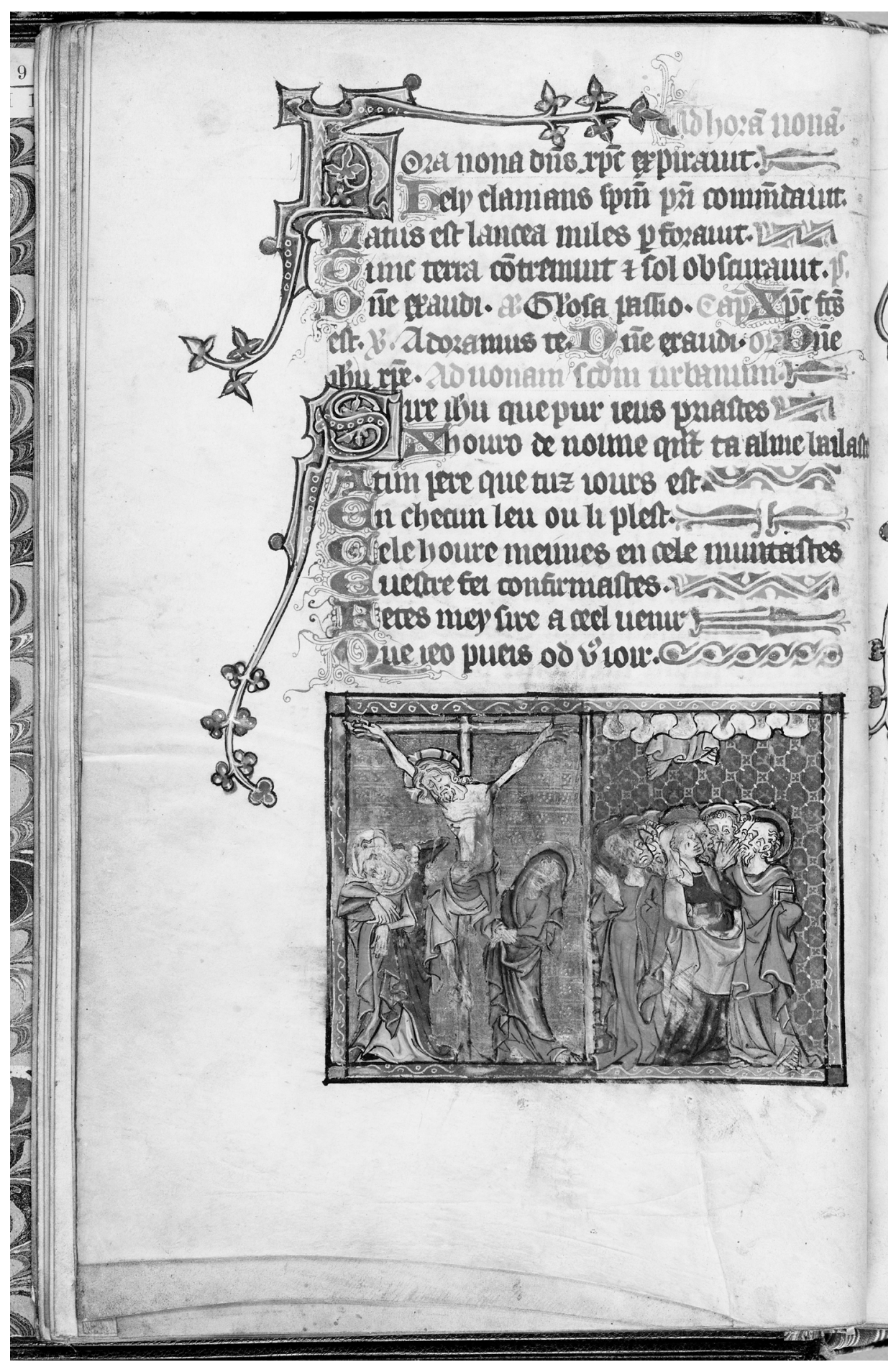

FIGURE 12. Crucifixion/Ascension, Deposition/Last Supper, diptychs from Nones and Vespers of the Short Hours of the Cross; Ellesmere Psalter-Hours, fols. 16v-17. 


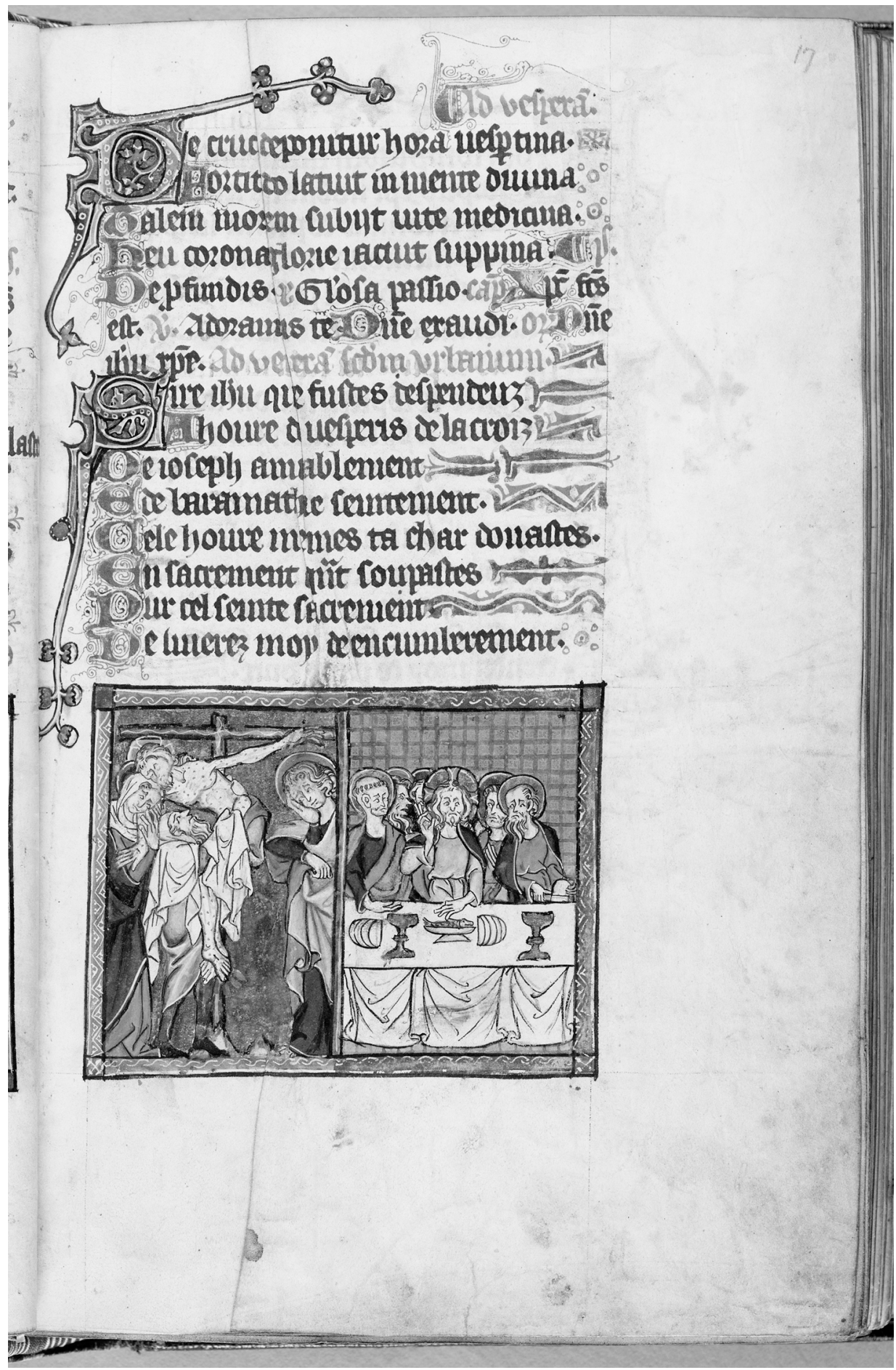




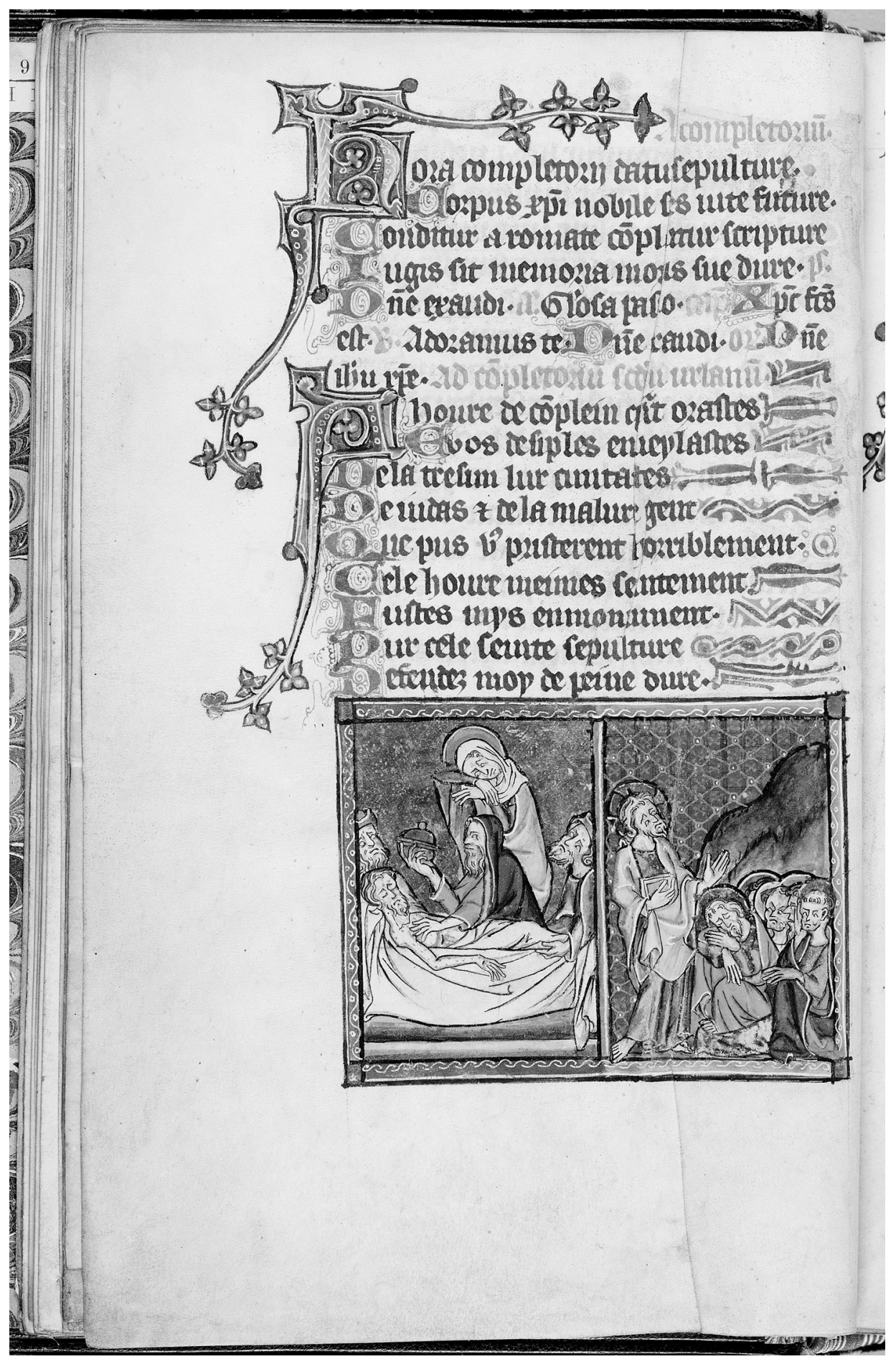

FIGURE 13. Entombment/Agony in the Garden, diptych from Compline of the Short Hours of the Cross; Ellesmere Psalter-Hours, fol. 17v. 
Christ's long post-prandial sermon, is transformed into a hybrid of the sermon and of the subsequent agony in the garden at Gethsemane. In reversing the two scenes both chronologically and in order of how they appear in the text above, the artist gives a neat twist to the end of the pictorial series, suggesting a final turn that will lead back to the beginning of the cycle. Furthermore, by exchanging the scene of the mutilated corpse with that of the upright, preaching figure of Jesus, the cycle can close with a living image of Christ as a teacher, and the viewer can identify with the apostles whose attention to his words serve as an example for all Christians.

In addition to responding sensitively to the poem's nuances, the Ellesmere artist also captured the very mystery at the heart of the poem. Christ's dual and synchronous identity as suffering man and triumphant god is made manifest in the pictures in a manner entirely outside the scope of verbal expression. Grasping the essential perceptual advantage of the pictorial medium over the verbal medium in this respect, the painter explores the issue of instantaneity. Sometimes, as in the miniature for Tierce, the temporally distinct events of the two valves of the diptych are tied together by visual means-here, the thongs of the whip in the hands of one of Christ's tormentors (fig. 11). Furthermore, a series of calculated violations of the frame, such as the arm of the cross that intrudes into the left margin at Sext, remind the eye that the picture belongs to the material support of the page and that it coexists with the Latin and Anglo-Norman words; in the visual field, at least, all these things are always equally present, bound together by their material nature and by the conditions of viewing.

The poem's insistence on what is patently impossible in verbal terms-that is, the synchronicity of Christ's human suffering and divine triumph-gives the poem its force as a devotional tool, despite its metrical difficulties and occasionally strained rhymes. The pictures, harmonized with the content and even the form of the poem but set against the diachronic tension of the words, quite literally illustrate what cannot be directly represented linearly, in language. Christ is both humiliated and ascendant, both suffering and triumphant, both human and divine, and the sinful soul of the reader is simultaneously urged to pity and to piteousness. The complementary relationship between word and image points toward a strong understanding of the text on the part of the artist. That is, the artist understands the poem's spiritual intent and communicates this understanding visually, translating, and indeed transforming, the temporal tension at the center of the poem.

Such similarities and connections between the Anglo-Norman text and the miniatures demonstrate that the illuminator was actively responding to the poem both in its material form on the page, engaging it visually, and in its literary dimensions, reading it thoughtfully and translating its poetics into a pictorial idiom. This engagement speaks volumes about the role of artists in not just reproducing but also shaping approaches to devotion. It also stands in strong contrast to the conservatism of the pictorial program in the Psalter, with its conventional cycle of Psalm initials along with its consistently Latin textual contents and its concern with both lineage and the vexed issue of English kingship. The Psalter speaks of an environment in which both patrons 
and artists viewed the book as much more than a useful tool for devotion; it is a sign for the particular affinities of its makers and users, and these affinities range from the local devotion to Lichfield saints to regional genealogical and political ties, encompassing other loyalties and aspects of identity.

The utility of such a book to the devotions of its primary owner, perhaps the woman depicted in the initial on folio 175 , is indisputable, but whether she actually read or could read the Latin is another question. It may have been the case with this as with other luxury Psalters that the point was more to have a book that contained and made visible the text than to have a book one actually sat down and read in any fashion that monks, scholastics, or modern people would recognize. In favor of such an argument are the very words in the book open before the lady as she prays-not those of the Psalm but of the Ave Maria, one of a small number of prayers that the Church demanded the laity have by heart.

By contrast, the Hours portion of the Ellesmere manuscript displays an inconsistent but at times passionate engagement with words as such. Its unique strategy of joining Latin, Anglo-Norman, and pictorial text in the Short Hours of the Cross argues for a strong interest in creating a book that invites reading rather than one that structures recitation. Even more provocative is that even the Anglo-Norman language of the vernacular verses was not the primary language of the book's intended audience or of the English illuminator who painted the seven diptych images that accompany it. As a vernacular, then, it occupied an odd space between Middle English and Latin. It was an elite language, but the elite to which it belonged was in the process of losing it. Why not just insert a Middle English text here if you really aim for readability?

The answer lies in the relation between the Hours and the Psalter portions of the book. Where the Psalter expresses its concern with noble identity through its stylistic choices, its Latinity, and its emphasis on heraldry, the later Hours engages with the question of its owner's loyalties and class identity through language and through the imagining of an exemplary piety that is intensely visual, somatic, and imaginative. Perhaps the aging Isabel de Harcla, embittered by the events of the early 1320s, including her brother's condemnation and execution for treason, her husband's probable captivity in Scotland, and the death of her son, turned to new and more emotionally cathartic ways of exploring and expressing both her personal identity and her relationship to God. Or perhaps she was tougher than that, and commissioned the new Hours portion of the manuscript from the same impulse toward display that motivated the making of the Psalter a decade earlier, following the latest trend in conspicuous piety to announce that despite everything, she was still a grande dame. In any case, the cognitive distance between the two parts of the Ellesmere Psalter-Hours makes the manuscript a valuable document for our understanding of the rapid pace of change in religious behavior and experience, artistic practice, and patterns of self-fashioning in early fourteenthcentury England. As Eamon Duffy has observed, the prayer books of the late medieval laity corresponded not only to an increasingly intimate and emotional tenor in reli- 
gious life but also to what he calls "a robust interest in measurable results." 70 What worked for the de Vernon family in about 1310 probably didn't work quite so well in 1325, and required some adaptation. The role of the painter and scribe in providing the material for such adaptation is clear, and serves as yet another reminder of the often overlooked agency of visual artists in the shaping of the late medieval world.

This article was conceived and researched with support from an A.W. Mellon Foundation Fellowship at the Huntington Library and further grant support from the American Association of University Women Educational Fund. I would also like to thank the following archivists and local historians who kindly helped me track down documentation: the Reverend Colin Honour of Urswick Church, Ulverston; Ian Caruana, librarian of the Cumberland and Westmorland Antiquarian and Archeological Society, Carlisle; Sarah Gates, archivist, Shropshire Archives, Shrewsbury.

ALEXA SAND is an associate professor of art history at Utah State University. She is the author of Vision, Devotion, and Self-Representation in Late Medieval Art, forthcoming 2013, a study of the emergence of owner portraiture in thirteenth- and fourteenth-century prayer books for the laity. She has published a number of articles on devotion and representational practice in the late medieval and Renaissance periods, and she is currently working on the manuscripts and early print editions of the French vernacular moral treatise La Somme le Roi.

70. Eamon Duffy, Marking the Hours: English People and Their Prayers, 1240-1570 (New Haven, Conn., and London, 2006), 64. 